\title{
How to win the battle of ideas in corporate social responsibility: the International Pyramid Model of CSR
}

\author{
Najeb Masoud
}

\begin{abstract}
This paper reviews the definitions of Corporate Social Responsibility (CSR) as they have evolve over time. It traces the origins of the concept and creates a theoretical framework for international use, thus having the benefit of applicability in both developing as well as developed economies. The models of Carroll and Visser are integrated to produce The International Pyramid Model of CSR, which acknowledges the relative importance of economic, glocal, legal and ethical, and philanthropic aspects of the CSR concept. The primary innovation in the International Pyramid is the development of 'glocal' responsibilities, relating to the environment, socio-cultural matters, technology users, and political rights. Additionally, the International Pyramid condenses Carroll (Business Horizons 34(4):39-48, 1991) pyramid such that the separate legal and ethical responsibilities are merged into one 'legal and ethical' obligation. Furthermore, it offers flexibility by acknowledging that the various responsibilities it embodies can shift up or down the pyramid as priorities change, which is inevitable as businesses and economies differ cross-sectionally, and over time.
\end{abstract}

Keywords: Corporate Social Responsibility, Carroll's Pyramid Model, Visser's Pyramid Model, International Pyramid Model

JEL Classification: A1, G30, K4, M2, M14, O10

\section{Introduction}

The idea of corporate social responsibility (CSR) has become an important one over the last few decades, gradually evolving to reach today's understanding. However, recent studies have suggested that this understanding of CSR and the way in which it is implemented differs across countries, and time, and that it is the various business communities that have determined the pace of evolution and development in this respect. In fact, CSR has been represented as an umbrella-term covering a diverse range of issues which have grown steadily in importance for business performance at a global level. Porter and Kramer (2006, p.78) argue that, under the scrutiny of government bodies, and activist shareholders, CSR is "an inescapable priority for business leaders in every country". Hence, as noted by Maron (2006), CSR is applicable in global contexts and a practicality to be absorbed by all businesses within their available

Correspondence: najeb2000@gmail.com

Department of Accounting, Aqaba University of Technology, Amman, Jordan resources. Simultaneously, numerous researchers have noted the variation in usage of the associated concepts (Garriga and Mele 2004) as well as the identification of the concrete actions which should be considered (Dahlsrud, 2008).

In order to conduct this comprehensive definitional review, and make sense of the continual contributions to more recent conceptual analyses of CSR, it is necessary to begin with the early literature pertaining to CSR which has its roots in the 1950s and 1960s. From that point, the review proceeded through the 1970s, when the topic became more widely discussed among academics, scholars and business community practitioners. In the 1980s, there were fewer new definitions, and companies began to accept that their business and social interests should be part and parcel of their overall operations; and were subsequently more responsive in this connection. By the 1990s, the idea of CSR had become almost universally accepted into alternative 
thematic frameworks. The 2000s saw CSR having achieved the status of an element of corporate strategy.

Dozens of definitions of CSR have arisen in recent years in attempts to articulate the key issues. Indeed, Dahlsrud (2008) provided an analysis of 37 different definitions of CSR, acknowledging that his study did not actually capture all those in existence. The widely-cited definitions, however, are those provided by Carroll (1979, 1991), Visser (2011), and the European Commission (2011). Carroll's four-part definition of CSR was originally stated as follows: "Corporate social responsibility encompasses the economic, legal, ethical, and discretionary (philanthropic) expectations that society has of organisations at a given point in time" (Carroll 1979, p.500). Visser (2011, p.1) states that CSR is "the way in which business consistently creates shared value in society through economic development, good governance, stakeholder responsiveness and environmental improvement"; and the European Commission (2011, p.2) defines CSR as "a concept whereby companies integrate social and environmental concerns in their business operations and in their interactions with their stakeholders on a voluntary basis", although it has also proposed a simple definition, that being "the responsibility of enterprises for their impacts on society".

The purpose of the concept of CSR, and hence the article is threefold, as follows: 1) to contribute to the existing major theoretical approaches in respect of CSR; 2) to build upon the two Pyramid CSR models developed by Carroll and Visser, for use in the US and in developing countries respectively; and 3) to present a new original model entitled the International Pyramid as the basis for practising CSR. In this article, we argue the usefulness of this new model - the International Pyramid Model of CSR - as being the fact that it is grounded in the foundations of institutional business responsibilities, that the majority of previous models of CSR lack to society. At this stage, it is important to mention that the International Pyramid model of CSR embodies a universal hierarchy applicable to all professions, and that consequently, it can be adapted to different social, cultural, and temporal contexts, and serve as heuristics that facilitate more managerial reflection and better decision-making. Depending upon the profession, and business aim, the responsibilities within the International Pyramid could be easily arranged to suit the needs of different countries worldwide, because regardless of the ranking, it is necessary to cover all levels of corporate responsibility in order to undertake business in a socially responsible way. In other words, to be socially responsible implies that companies should consider all their responsibilities, and allocate sufficient funds and other resources to enable increases in capital spending, create jobs, and make contributions to the local and wider community through various forms of engagement and education. The economic responsibilities are positioned in the first tier of the International Pyramid, the glocal responsibilities in the second, the legal and ethical responsibilities in the third, and the philanthropical responsibilities in the fourth. These are offered as a response to social goals and expectations, and are discharged via charity contributions addressing community and social concerns.

Writing a substantive history of CSR since the 1950s requires attention to wide-ranging social, political, and economic changes along multiple dimensions. It is not simply a story of corporate actions. In the following sections, the literature relating to CSR is reviewed, thereby presenting a full conceptual analysis, and a comprehensive picture of how this is practised. This allows for the development of the new CSR framework (the International Pyramid), which is presented after the review to tell the full story, and thereafter follows a conclusion.

\section{Literature review}

In reviewing the literature, the work of many scholars and researchers has been considered. Especially, contributions by Carroll (1999, 2008), Schwartz and Carroll (2008), Carroll and Shabana (2010), which provide a comprehensive history of social community development, and those by Preston and Post (1975), Crowther (2008), and Windsor (2001), which focus on the core academic literature are also reviewed. Carroll (2008) notes that the roots of the concept, as we know it today, have a long and wide-ranging history. Indeed, Mohan (2003), and Gond and Moon (2011) trace these back to the 1920s when the concept began to escalate in the realisation that CSR was important for business success. It is clearly important to chart this progression in understanding and acceptance, and hence, the literature is reviewed on a historical basis, with the aim of appreciating what CSR has meant in the past and what it means today. Figure 1 provides an illustration of how the concept of CSR has evolved in both managerial and academic terms since that time.

In the early writings on CSR, the concept was more often referred to as social responsibility (SR) than as CSR. The evolution in this respect can be seen through the main phases of development which are: the 1950-1960s which represented the period when CSR was introduced in the academic arena and in corporate philanthropy; the 1970s which saw a period of rapid growth in the concept of CSR; the 1980s when stakeholder theory and business ethics came to the fore; the 1990s in which CSR was seen to be practised by corporate organisations; and the year 2000 onward, since when much empirical work investigating the determinants of CSR, its embodiment in corporate strategy, and the consequences of its effective implementation, has been undertaken. 


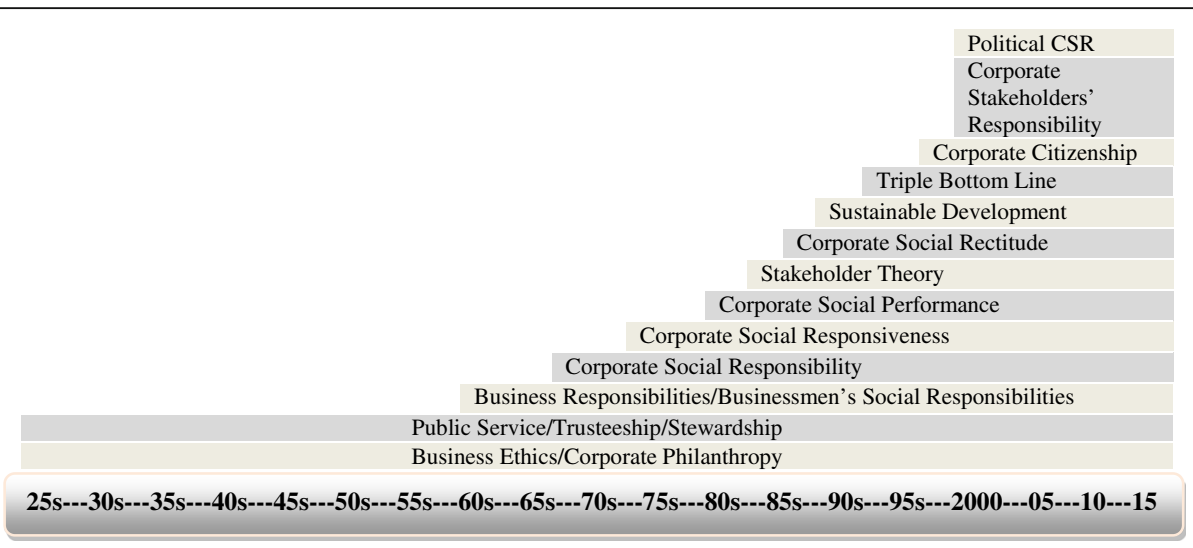

Fig. 1 The escalation of CSR concepts. Source: Adapted from Mohan (2003, p.75), and Gond and Moon (2011, p.11)

\section{CSR Roots in the 1950s}

The roots of CSR can certainly be seen before World War II (Carroll and Shabana, 2010, p.86). Indeed, in 1916, Clark published his famous article entitled the "Journal of Political Economy", in which he expressed the idea that: "[...] if men are responsible for the known results of their actions, business responsibilities must include the known results of business dealings, whether these have been recognised by law or not" (p. 223). Ten years later, in 1926, Clark published the first edition of his book Social Control of Business, in which he argued that the basic structure of modern society does not rest in competitive economic development (Janowitz, 1975), but rather in social control. 'Social control' as a concept first appeared in 1894, in the writings of Ross, who believed this to be the key that unlocks many doors (Ross, 1901). During the 1920s it served as the root for the concept of business ethics or corporate philanthropy as evidenced via public service (Smith 1987) and trusteeship (Clark, 1939). In 1942 Drucker developed a social theory in his second book entitled The Future of Industrial Man, in which he argued that companies have a social dimension as well as an economic purpose, and that this social dimension primarily addresses issues of responsibility and the preservation of freedom (Drucker, 1942). As a result, in the late 1940 s and during the 1950s, the primary developing body of knowledge on CSR was determined by the business organisation of social responsibility (Lafferty, 1996), as a means of doing good deeds for society (Carroll and Shabana, 2010). However, it is clear from Bowen's (1953) arguments in his landmark book Social Responsibilities of the Businessman that social responsibility cannot be viewed as a panacea for all the social problems encountered by businesses, but that nonetheless, businesses must be guided by such responsibility, and attempt to determine whether indeed they do have social responsibilities to discharge or not (1953, p.6). Carroll (1999, p.270) argued that due to Bowen's early seminal work on this concept, he can be considered the "father of corporate social responsibility" since this work marks the beginning of the modern period of literature on CSR.

Further evidence of the extent to which businesses had adopted and were practising CSR during this time and earlier, has been provided by Frederick (2006) who explains what CSR meant in the 1950s by referring to three core ideas, these being: the idea of corporate managers as public trustees, the idea of balancing competing claims to corporate resources, and the acceptance of philanthropy as a manifestation of business support for good causes. Drucker was one of the first theorists to explicitly address CSR in his 1954 book, The Practice of Management. In this, he followed the same ethical obligation argument used by Bowen to recognise the growing requirement for eight key areas to be considered when devising business objectives. Specifically, he argued that "the proper 'social responsibility' of business is to tame the dragon that is to turn a social problem into an economic opportunity and economic benefit, into productive capacity, into human competence, into well-paid jobs, and into wealth" (Drucker, 1984, p.26). However, the decade of the 1950s was more one of talk, especially among academics, than of action with respect to CSR.

\section{CSR as Philanthropy in the 1960 s}

Although the CSR literature expanded significantly in the 1960s, it had a specific focus on the question of what social responsibility meant, and on its importance to both business and society (Carroll, 1999; Carroll and Shabana, 2010). One of the most prominent writers during that period was Keith Davis, who argued that CSR refers to the firm's consideration of, and some decisions made by businessmen (1960, p.70). Another major contributor to the definition of social responsibility in this decade was Joseph McGuire, who stated in his book Business and Society (1963, p.144), that "[t]he idea of 
social responsibilities supposes that the corporation has not only economic and legal obligations but also certain responsibilities to society which extend beyond these obligations". Thus, the definitions of CSR during the 1960s represented an attempt to establish the link between business and society. In fact, that effort was continued by a number of academics and researchers over the next two decades (1970s-1980s), and still features as an issue of discussion today. As in the 1950s, however, there was still more talk than action on the CSR front, according to McGuire (1963).

\section{Period of rapid growth in the concept as CSR during the 1970s}

In the 1970s, increasing reference occurred to the ideas of corporate social responsiveness (see Ackerman, 1973; Ackerman and Bauer 1976) as a vehicle for CSR, and corporate social performance (CSP). One of the best-known writers to make this distinction was Sethi $(1975$, p.60) who discussed "dimensions of corporate social performance", focusing on the distinguishable corporate behaviours relating to "social obligation", "social responsibility", and "social responsiveness", and defining social obligation within corporate behaviour as a "response to market forces or legal constraints". Another significant contribution to the CSR concept in the 1970s was made by Carroll (1979, p.499) who offered a basic theoretical model of corporate social performance (CSP). He argued that in engaging in CSR, organisations must: (1) adopt a basic definition of CSR that could be identified within their business; (2) identify the issue for which a social responsibility existed (or, in modern terms, the stakeholders to whom the firm had a responsibility, relationship, or dependency); and (3) specify the philosophy (or strategy) of responsiveness to the issues. He then postulated the following definition: "the social responsibility of business encompasses the economic, legal, ethical, and discretionary expectations that society has of an organization at a given point in time" (Carroll, 1979, p.500). The threedimensional model of CSR postulated by Carroll incorporates four layers which he labelled economic, legal, ethical and discretionary (philanthropic) responsibilities (see Fig. 2), as a reflection of the fact that "the history of business suggests an early emphasis on the economic and then legal aspects and a later concern for the ethical and discretionary aspects" (Carroll, 1979, p.500). Carroll (1979) believed that this characterisation helps the manager to appreciate that the different types of obligation are in constant tension with one another.

The work of Milton Friedman (1970) also provided researchers with a topic for debate, with the discussions generated in academic circles being considered "a major contribution to the development of the corporate social responsibility theory" (Lucas et al., 2001, p.150). This work was taken up by Harold Johnson (1971, p.50) who wrote of "conventional wisdom", defining a socially responsible firm as one which made "larger profits for its stockholders ... [and] takes into account employees, suppliers, dealers, local communities, and the nation". $\mathrm{He}$ also observed that "[s]ocial responsibility states that businesses carry out social programs to add profits to their organisation" (p.54), and talked of "utility maximization", evidenced when "the enterprise seeks multiple goals rather than only maximum profits" (p.59). Finally, Johnson offered the "lexicographic view of social responsibility", explaining that "lexicographic utility theory suggests that strongly profit-motivated firms may engage in a socially responsible behavior. Once they attain their profit targets, they act as if social responsibility were an important goal - even though it isn't" (p.75).

However, the most significant contribution on the concept of CSR came from the Committee for Economic Development (CED), which observed that "business is a function by public consent and its basic purpose is to

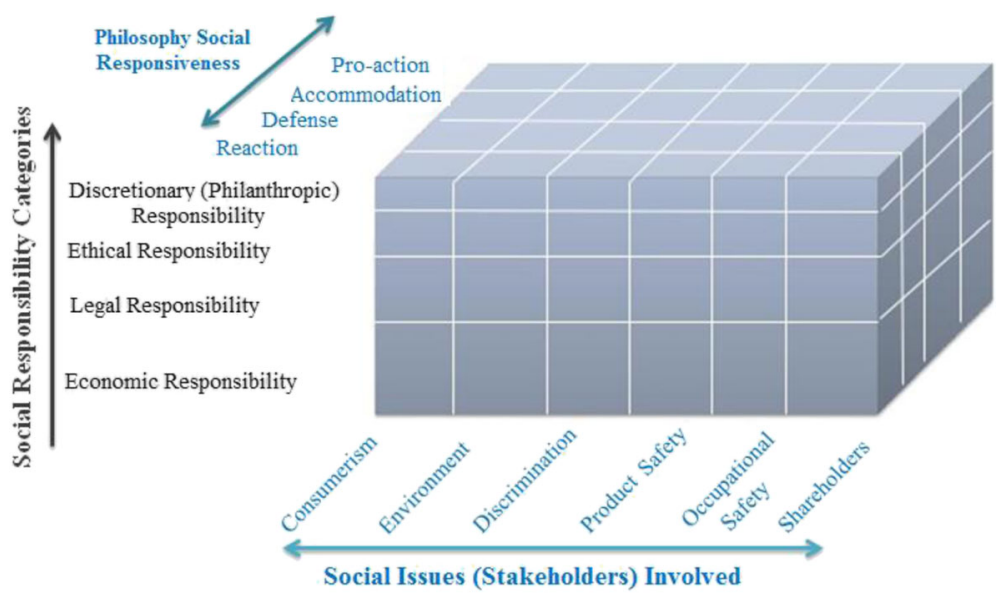

Fig. 2 Carroll's Three-Dimensional Conceptual Model of Corporate Performance. Source: Carroll (1979) 
serve constructively the needs of society to the satisfaction of society" (1971, p.11). In this respect, the CED may have been responding to the current trends in which social movements with respect to the environment, employees, consumers, and worker safety had recently transitioned from special interest status to formal government regulations in the late 1960s and were continuing to do so in the early 1970s (Carroll, 2008). It is clear that more talk than action on the part of companies occurred during this decade, but companies did create organisational mechanisms to comply with federal laws dealing with the environment, employment discrimination, product safety, and worker safety (Carroll, 2008).

\section{Stakeholder theory and business ethics as CSR in the 1980s}

In the 1980s, the focus on developing new or refined definitions of CSR continued, bringing with it concepts and themes such as corporate social responsiveness, corporate social performance, public policy, business ethics, and stakeholder theory/management, just to mention a few (Carroll, 2008, p.34). Two very important alternative themes to CSR that emerged during this period were stakeholder theory and business ethics, contributions that came mostly from Freeman (1984, 1994), Wartick and Cochran (1985), Evans and Freeman (1988), Freeman and Phillips (2002), and Phillips et al. (2003). As explained by Freeman (1984, p.5), "Our current theories [stakeholder theory] are inconsistent with both the quantity and kinds of change that are occurring in the business environment of the 1980s [...] A new conceptual framework is needed". As observed by McWilliams and Siegel (2001), several other authors agreed with this opinion. Indeed, the observation of Wheeler et al. (2003), p.20) was that "[s]takeholder theory has never been just about social issues [...], sustainability is not just about environmental issues [....] And there is no necessary dichotomy between sustainability and profitability". Carroll (1991, p.43) provided a link to stakeholder theory by noting the "natural fit between the idea of CSR and an organization's stakeholders". Furthermore, other researchers such as Key (1999, p.317) identified certain limitations of the stakeholder theory, claiming that Freeman's conceptualisation only applied to the external environment and neglected some important components, such as: CSR1 (responsibility), CSR2 (responsiveness), and CSR3 (rectitude). Later, Muirhead (1999) classified the period from the mid-1950s to the mid-1980s as one of "growth and expansion" of corporate contributions.

One of the most important scholars in this period was Thomas Jones (1980), who placed an emphasis on CSR as a process (Carroll, 2008) rather than a set of outcomes (Jones, 1980). Two aspects of this definition are critical, the first being that "the obligation must be voluntarily adopted; behaviour influenced by the coercive forces of law or union contract is not voluntary. The second is that the obligation is a broad one, extending beyond the traditional duty to shareholders to other societal groups such as customers, employees, suppliers, and neighboring communities" (Jones, 1980, p.59-60). Jones (1980, p.6) believed that "corporate behaviour should not, in most cases, be judged by the decisions actually reached, but by the process by which they are reached" (Jones, 1980, p.65). In tracing the relationship between CSR and firm profitability since the 1980 s, Carroll (2008, p.35) pointed out that 'the quest in the 1980s to 'go beyond' CSR was the growing acceptance of the notion of 'corporate social performance' as a more comprehensive theory under which CSR might be classified or subsumed". In the main, the 1980 s was marked by the stakeholder theory which was further developed into a more holistic approach in the 2000s to describe the concepts of CSR.

\section{CSR in business practice during the 1990s}

During the 1990s the idea of CSR became almost universally approved. This was a period which Muirhead (1999) characterised as one in which corporate contributions became diversified and globalised. For example, contributions were made to the following concepts: corporate social performance (CSP), stakeholder theory, business ethics, sustainability, 'triple bottom line' and corporate citizenship, thereby making these the most important constructs that concerned researchers (Carroll, 2008). Elkington (1999) formulated the concept of "triple bottom line" (or 3BL) and linked it to the idea of sustainability using stakeholder theory to measure and manage the impact of CSR upon social, environmental, and economic performance. Carroll (2015, p.89) comments on this development, saying that during the "90s the notion of the strategic, bottom line, relevance of social responsibility began to be framed as whether a 'business case' for CSR could be made. Even with earlier CSR initiatives, there was frequently the built-in premise that socially responsible firms would not only be enhancing the society in which they existed but that their efforts would be in their long-term, enlightened selfinterest".

Carroll's own CSR model was first presented in 1991, as a pyramid constructed after revisiting his original 1979 four-part CSR framework developed in the context of American-type capitalistic societies. This pyramid was an attempt to provide a more specific definition of the discretionary component as philanthropic, suggesting it to embrace corporate citizenship. Carroll (1991) organised his pyramid as a four-layered model, entitled the Pyramid of Responsibilities, which embodied the four different responsibilities - economic, legal, ethical, and philanthropic - which while not mutually exclusive, 
enabled managers to appreciate the varying types of obligation and the continual tensions between them. Carroll (1991, p.40) acknowledged that none of the four responsibilities were new to the CSR concept, but argued that it was only recently that the significance of the ethical and philanthropical functions had assumed prominence. Figure 3 depicts Carroll's Pyramid of CSR. However, Clarkson (1999) criticised Carroll's conceptual model for its complexity, the difficulties associated with testing it, and its failure to advance the methodology in respect of collecting, organising, and evaluating corporate data. That said, this pyramid has served to inspire other researchers, Gholami (2011) being one such scholar who has built upon Carroll's (1991) four-dimensional Pyramid model to consider the creation of value for both the organisation and society.

Certainly, the four-part CSR model has been empirically tested over many years, Aupperle et al. (1985); 1983) conducting the first such test by surveying 241 Forbes 500-listed CEOs using 171 statements about CSR. Their statistical analysis supported the model in two ways: (1) by confirming that there are four empirically interrelated, but conceptually independent components of CSR; and (2) by giving tentative support to the relative weightings which Carroll had earlier assigned to each of the four components. Another empirical study undertaken by Edmondson and Carroll (1999) used Carroll's CSR Pyramid for a sample of 503 large Black-owned businesses in the US, suggesting the importance of culture in attitudes to CSR (Edmondson and Carroll 1999). The outcome of such interest was the introduction in the 1990s of the Institution of Business for Social Responsibility (BSR), formed to represent the initiatives and professionals having responsibility for CSR in their companies (Carroll, 2015, p.89).

In general terms, the social performance resulting from a company's CSR operations is referred to as CSP, and in 1991, Wood made contributions to the major CSP model built by Carroll in 1979, which had already been reviewed by Wartick and Cochran in their model of 1985 (Carroll, 1999). Wood's model was much more comprehensive than the earlier versions of Carroll (1979) and Wartick and Cochran (1985), since the presence of CSP views the company as the locus of actions that have consequences for stakeholders and society as well as for itself (Wood, 2010). In particular, Wood's model developed the research areas of social responsibility behaviour, processes of responsiveness, and outcomes of performance. In it, corporate sustainability performance is defined as: "a business organization's configuration of principles of social responsibility, processes of social responsiveness, and policies, programs, and observable outcomes as they relate to the firm's societal relationships [and its outcome]" (1991, p. 693). Outcomes are divided into three types: the social impacts of corporate behaviour, the programmes used by companies to implement responsibility, and the policies developed by companies to handle social issues and stakeholder interests, as outlined in Table 1.

Although, as noted by Meehan et al. (2006), Wood's model played an important role in theoretical research, it was, however, unsuccessful in investigating the practical needs of managers in their efforts to implement CSR and evaluate its basic effects. Indeed, both conceptual models are likely to develop theory and research in CSR rather than having any concrete practical impact. These criticisms aside, however, by the late 1990s the idea of CSR had become almost universally sanctioned and promoted by all constituents in society from governments and corporations, to non-governmental organisations and individual consumers (Lee, 2008, p.53).

\section{Empirical work on CSR (2000 onwards)}

Since the start of the new millennium, the debate concerning CSR has been taken up globally by academicians wanting to further research and identify new areas within the overall phenomenon of such responsibility. This more widespread interest has revealed that important inter- and even intra-regional variations exist in practice (Carroll, 2008), with it being evident as identified by Carroll (2008,

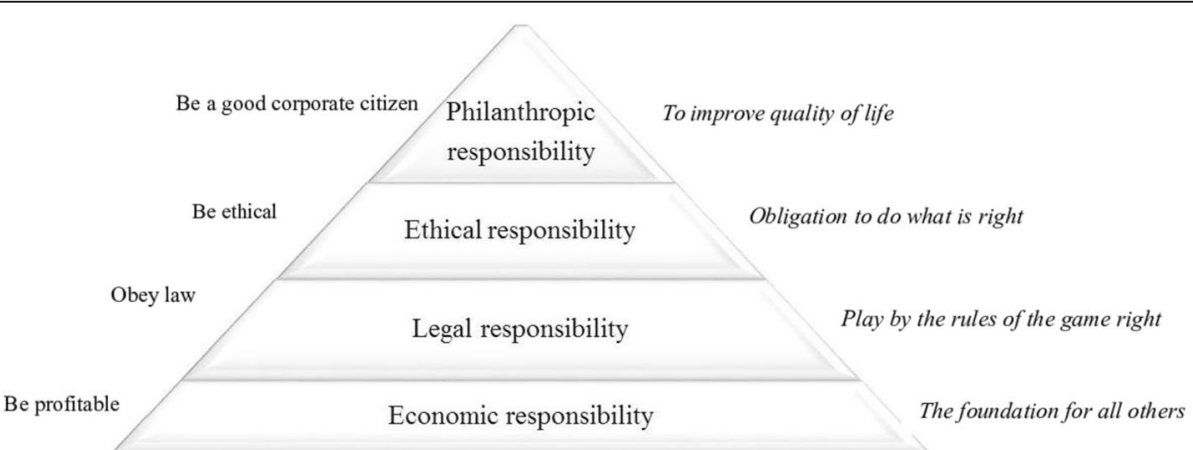

Fig. 3 Pyramid model of CSR. Source: Carroll (1991, p.42) 
Table 1 The corporate social performance model

Principles of CSR
Institutional principle: legitimacy
Organizational principle: public responsibility
Individual principle: managerial discretion
Processes of CSR responsiveness
Environmental assessment
Stakeholder management
Issues management
Outcomes of corporate behavior
Social impacts
Social programs
Social policies

Source: Wood (1991, p. 694)

p.41), that "some initiatives are more voluntary than others as some companies have been under legal and regulatory pressure to adopt them". Such pressure has been criticised by Jensen (2002) who argues that social responsibility should not be incorporated as a business aim on the grounds that businesses already contribute to society by making a profit. He states that "200 year's (sic) worth of work in economics and finance indicate that social welfare is maximized when all firms in an economy maximize total firm value" (p.239). Margolis and Walsh (2003, p.271) commenting on Jensen's position, state that those subscribing to this view "believe that if shareholder wealth is maximized, social welfare is maximized as well".

Within this argument is the emphasis on performance, an idea which has gained popularity because the terminology, which has evolved throughout the development of CSR over the last 50 years, has been very result-oriented. Clearly, there are multiple interpretations of CSR given by different scholars and researchers, which include a focus on: 'business ethics and morality', 'corporate accountability', 'corporate citizenship', 'corporate giving and philanthropy,' 'corporate greening and green marketing,' 'diversity management,' 'environmental responsibility', 'human rights', 'responsible buying and supply chain management', 'socially responsible investment' and 'stakeholder engagement' (see for example, Madsen and Ulhoi, 2001; Moon, 2002; Wheeler et al., 2003). Other early frameworks for CSR that have featured substantially in the last half century include Carroll's ideas for corporate social responsibility (CSR), business ethics (BE), stakeholder management (SM), corporate citizenship (CC), and sustainability (SUS). Such images of CSR have often been used interchangeably by business organisations and managers. Yet a further concept of corporate citizenship was also introduced by Carroll as a continuation and deeper elaboration of his approach to the theory of corporate social responsibility, embracing: responsibility (commitment and responsibility to society), responsiveness (action, activity), and performance (outcomes, results). In his later versions, Carroll also offers a detailed historical background and perspective on the evolution of CSR (see e.g., Carroll, 2015). Figure 4 depicts the evolution of the theoretical work on CSR since the 1960s.

In addressing CSR in two major models, Carroll introduced certain changes to his original ideas expressed in 1979 (Schwartz and Carroll, 2003). Like the original model, the 1991 framework contains certain categories of responsibility, which are in general "defined in a manner consistent with Carroll's four-part model, with the exception that the philanthropic category is subsumed under the ethical and/or economic domains, reflecting the possible differing motivations for philanthropic activities" (Schwartz and Carroll 2003, p.508). However, this model of overlapping circles (a Venn diagram) includes further refinements to resemble a pyramid, reflecting a reduction of the four categories of CSR into three as economic, legal, and ethical domains. Figure 5 illustrates this refinement, showing that the philanthropic element is no longer classified as an individual area in a company, being subsumed under the ethical and/or economic domain in the belief that this provides a better way of classifying corporate activities (Schwartz and Carroll, 2003).

It is observed that Carroll has provided some of the most well-known literature in the field of CSR (Dahlsrud, 2006), and that his CSR categories have been used by numerous theorists and in many business texts. Indeed, Wood and Jones (1996, p.45 in Schwartz and Carroll, 2003, p.504), confirmed that "Carroll's four domains have 'enjoyed wide popularity among SIM (Social Issues in Management) scholars"'; and Crane and Matten (2004) describe Carroll's work as the most durable and widely cited in the literature. Hence, Schwartz and Carroll (2003, p.504) assert that "such use suggests that Carroll's CSR domains and pyramid framework remain a leading paradigm of CSR in the social issues in management field".

Many researchers such as Greenfield (2004), Maignan and Ralston (2002), McWilliams et al. (2006), Pearce and Doh (2005) have argued in their discussions of corporate management that it is good to do the right thing not only for its intrinsic value but also because as a way of behaving, it leads to doing things and performing better (Bhattacharya and Sen, 2004; Dunphy et al., 2003; Kotler and Lee, 2005). This belief underpins the enhanced debate among economists, who have mainly focused on two aspects. The first is the value creation realised through CSR (e.g., Garriga and Mele 2004; Dahlsrud 2008; Beurden and Gossling 2008; Dicken, 2011, etc.), how it can be measured and why it matters (Lepak et al., 2007; Turker, 2009; Jonikas, 2012), and the second is the reasoning behind companies' adoption of more sustainable improvements and the subsequent possibility of applying for some type of certification (Detomasi, 2007). 


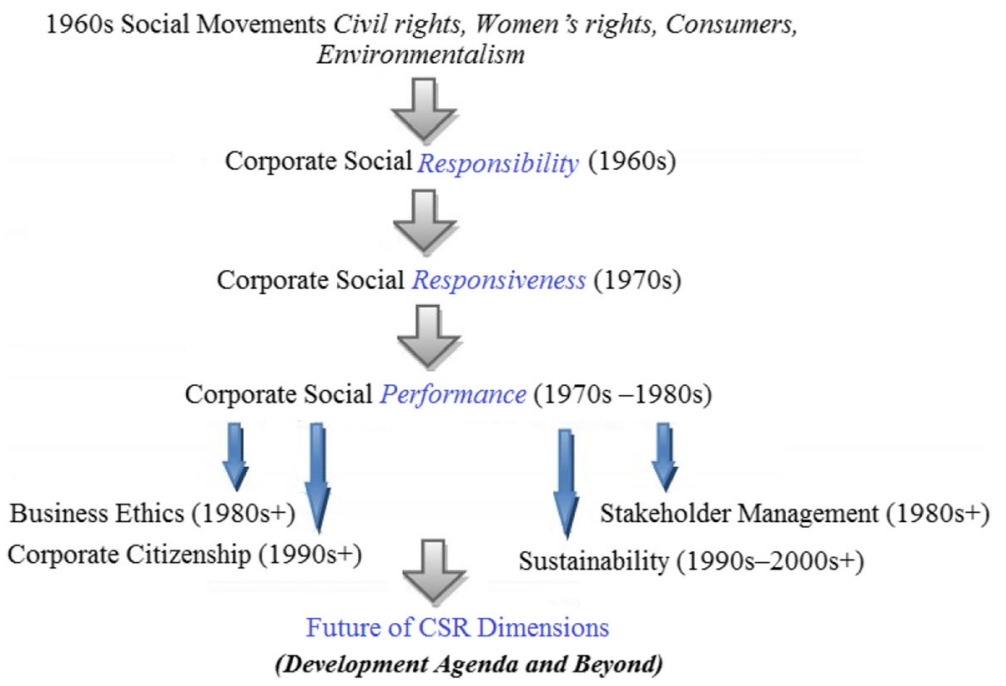

Fig. 4 50-year trajectory of corporate social responsibility (CSR). Source: Carroll (2015, p. 91)

\section{Developing a conceptual framework}

The development of an appropriate conceptual framework for CSR which allows for variation in organisations and contexts is important in order to highlight problem areas that need to be addressed by academics and practitioners in their discharge of such responsibilities. Once this type of framework is in existence, implicit practices can be made explicit. Hence, in this study, the intention is to transform the implicit framework in CSR into an explicit one. As Macve (1981, p.22) states: "Anyone recommending a particular [CSR] practice must necessarily base his views on an implicit conceptual framework - and it is therefore important, if there is to be rational discussion and evaluation of the proposal, to try and make that framework explicit".

Generally, a conceptual framework is a methodology used to establish a body of knowledge in a discipline by taking stock of, and codifying, the literature, which is in turn used to develop a model in such a way as to provide an easily understood way of interpreting the subject area, and present policy recommendations. Miller and Redding (1986), p.98) noted that: "In any field of study or activity, including [CSR] ... there are a number of reasons for developing a conceptual framework, which is a collection of broad rules, guidelines, accepted truths, and other basic ideas about the field". However, such frameworks are often open to criticism for their omissions relating to all the possible variables, and in the following sub-sections, the criticisms of the models discussed thus far, are considered.

\section{Criticisms of Carroll's pyramid}

Carroll's Pyramid is probably the most popular and established CSR concept, having become accepted as a paradigm, but it can be criticised on the grounds that like much of the CSR literature, it was generated within the US and thus, its global applicability is open to challenge. Indeed, several people have raised critical voices in regard to Carroll's Pyramid approach to CSR, with their main argument being that the model does not

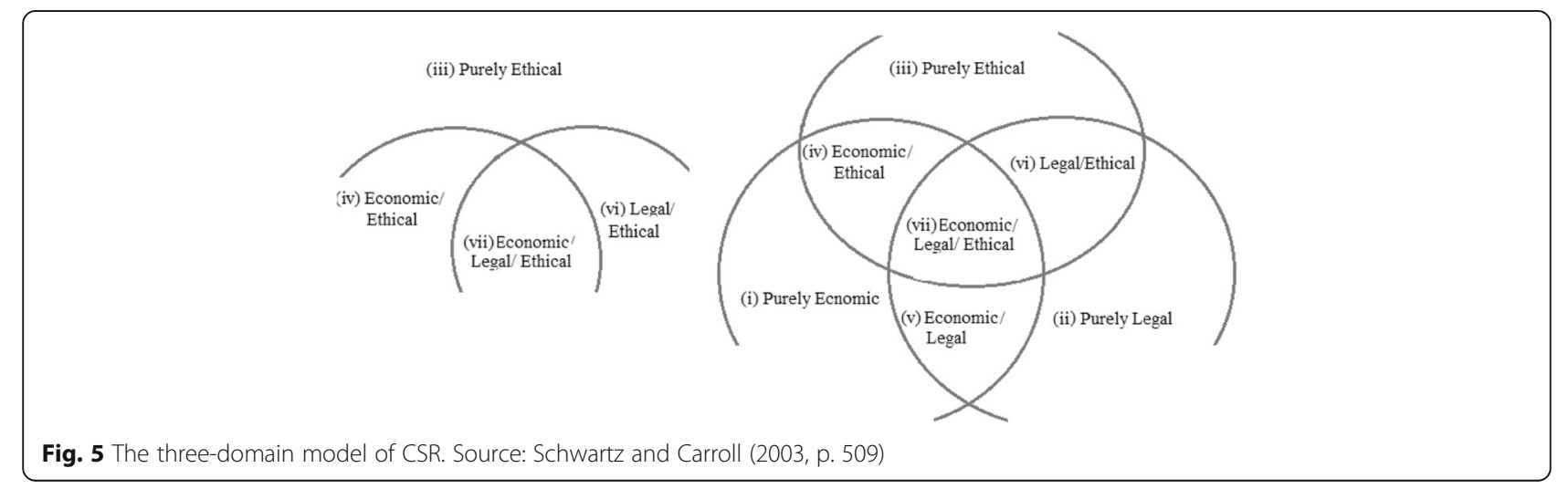


explain how the different responsibilities interact and influence one another (Visser 2006; Geva, 2008). Essentially, Carroll's two contributions (his original four-part construct in 1979, and the Pyramid model in 1991) were made in the context of developed countries, particularly American-type capitalistic societies, and this represents a failure in terms of transferability (see for example, Matten and Moon, 2005, p. 338; Visser 2006, p.36). Consequently, it is claimed that these contributions do not have the same value for developing countries. Additionally, Wartick and Cochran (1985) felt the need to develop Carroll's model to include the three-dimensional integration of responsibility, responsiveness, and social issues, while Wood (1991) took that extension even further. The efforts made by Wartick and Cochran (1985) and Wood (1991) recast Carroll's three aspects (corporate social responsibilities, responsiveness, issues), and actions into a framework (e.g. analysis, debate, and modification) of principles, processes, and policies. They argued that Carroll's CSR definition embraced three ethical components, i.e. social responsibility which should be thought of as principles, social responsiveness, which should be thought of as processes, and social issues management, which should be thought of as policies (Wartick and Cochran 1985, p.767). Carroll's model was also criticised by Aupperle et al. (1985) on the grounds that the philanthropic domain is hard to determine and evaluate. Another yet another criticism is that, in his effort to conflate various allied concepts such as business ethics, corporate citizenship, and stakeholder management into his own CSR Pyramid, Carroll fails to do justice these competing themes (Visser, 2006).

After the development of Carroll's second model, criticism came from Crane and Matten (2004, 2007a, 2007b) who argued that the framework does not address conflicting obligations and how culture manifests itself, and that Carroll fails to suggest how to resolve such conflicts (Visser, 2006). They came to this conclusion after applying it to CSR in a European business context, noting that "all levels of CSR play a role in Europe, but they have different significance, and furthermore are interlinked in a somewhat different manner" (p. 51). Visser came to the same conclusion when attempting to implement the model in respect of CSR in Africa. In reporting this effort in his article "Revisiting Carroll's CSR Pyramid: An African Perspective", he introduced the perspective of the model's usefulness in a developing environment, noting that it was indeed "a durable and useful model for defining and exploring CSR" (2006, p.45), yet suggesting that it may not be the best one for understanding CSR in general. Certainly, he acknowledged the application of the model in different countries, and observed the value of the different layers of the model, but his criticism remained. Indeed, despite its overall perception as being a valid CSR model, Carroll's Pyramid of CSR still receives criticism. Figure 6 illustrates the modified model.

\section{Visser's pyramid for developing countries}

Several CSR studies (for example, Baughn et al., 2007; Dobers and Halme, 2009; Lindgreen et al., 2009; Visser, 2006, 2008) have discussed the CSR practices in Africa and Middle East, Central and Eastern Europe, South and Latin America, and Asian countries. Visser (2006) developed a CSR model based on Carroll's (1991) CSR Pyramid Model for the developing countries in Africa. Not surprisingly, Visser's (2006, p.45) identification of the limitations of Carroll's model, including that relating to the model inconsistency in its explanation of why CSR is seen as a hierarchy, resulted in Visser's own response to improve the reliability of the model. Visser's argument was that as Carroll's model had not been tested outside of America, it failed to accurately provide a true picture of CSR when implemented elsewhere in the world, and especially in the African continent where the order of the CSR layers was observed to differ from that in the classic Pyramid. In addition, he rearranged Carroll's (1999) CSR pyramid and replaced discretionary responsibilities with philanthropic responsibilities. His finding was that in developing countries, economic responsibility continues to receive the most emphasis, with philanthropy being accorded the second highest priority, followed by legal and then ethical responsibilities, as depicted in Fig. 7. It is claimed that in the African CSR pyramid there is far less of a pressure for good conduct dictated by the law than in developed countries because of reasons such as a poorly developed legal infrastructure. In this respect, Visser (2006) suggests that, in practice, ethics remains the lowest CSR priority and that African countries are weak to adopt voluntary codes of conduct (Visser 2008, p. 491-492), but this does not necessarily mean that businesses do not comply with the law. He thus argued that his modified model was relevant in both an American and European context (Matten and Moon, 2008). However, even though Carroll proposed a linear evolution in the model where economic responsibilities came first and philanthropic responsibility came in the last stage of CSR maturity, a growing body of indication suggests that in developing countries, CSR practice is focusing on philanthropic responsibilities (Jamali and Mirshak, 2007; Visser et al. 2007; 2008).

Visser (2008, p. 474) mentions four reasons why it is necessary to try to develop a CSR model that will work for developing countries. Firstly, developing countries are growing fast in economies and this is, therefore, the productive market for business (IMF, 2006). Secondly, in developing countries, social and environmental crises are usually the most severe in the world (UNDP, 2006; 


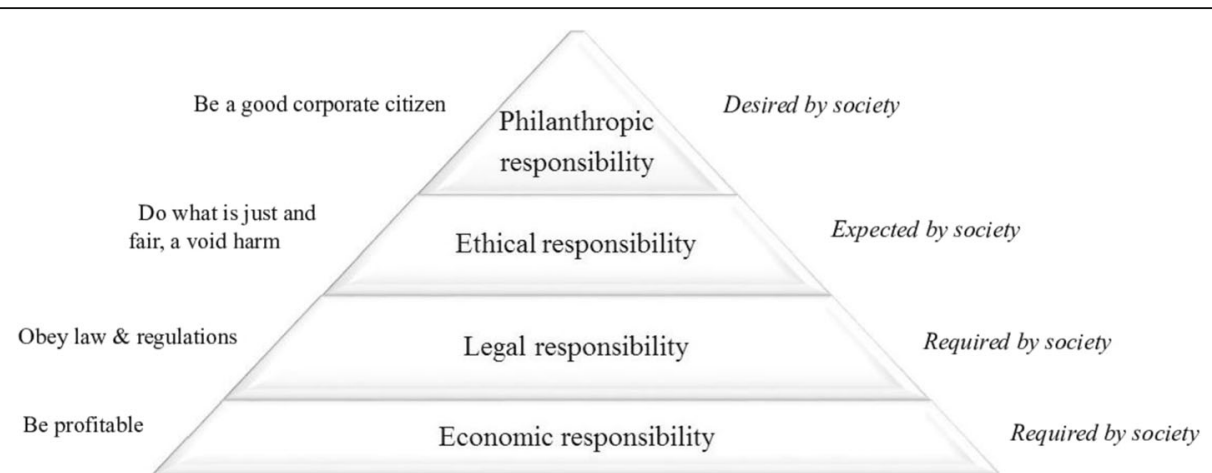

Fig. 6 Carroll's modified classic pyramid model of CSR. Source: Carroll $(2016$, p.8)

WRI World Resources Institute 2005). Thirdly, due to globalisation, economic growth, investment, and business activities, "both positive and negative" social and environmental impacts can have a significant effect on developing countries (World Bank 2006); and fourthly, there is a particular set of CSR programmes for developing countries which are generally completely different from those in the developed countries (Visser 2008, p.474). That's why CSR practices are important to the developing countries as is in developed countries, especially in contributing toward their socio-economic and environmental development.

\section{Other CSR models and their strengths and limitations}

To be fair, it must be acknowledged that some other theorists have made attempts to construct CRS models improving on those of Carroll and Visser as follows: The stakeholder theory, introduced by Freeman (1984), placed a large responsibility on stakeholders, recognising new kinds of obligations. However, there are many flaws in this idea, and consequently, the stakeholder approach is not as successful as the pragmatic approach in explaining how ethical behaviour can be implemented within a company (Claydon, 2011). Basically, the theory is vague; it does not provide clarification for specific scenarios and "did not provide a satisfactory pragmatic approach required by business managers in order to implement CSR" (Claydon, 2011, p.409). Stieb (2009) states that the stakeholder theory raises more questions on the role of the business in society than it provides answers. Marsden and Andriof (1998) who constructed their 'ripple effect' model based on the concept of the 'triple bottom line' considering the three goals of economic, social and environmental health. However, this model does not explore in detail what to do and how to understand the role of green technology in environmental preservation; and as noted by Kennedy (2001), whilst ethical investigation was once considered 'quaint', it now demands more attention and respect as it captures a larger share of the market and often offers enviable returns. Aras and Crowther (2009) created their 'Model of Sustainable Development' to achieve sustainability by using four actions: economic activity, conserving the environment, ensuring social justice, and developing spiritual and cultural values. Their model brings a broad view of CSR practices without pointing out specifically what should be done to ensure environmental protection and sustainability. It is still not a model that could enable truly successful implementation of CSR (Visser, 2010). Visser (2008, and further works e.g. 2010, 2012) proposed his "CSR 2.0" business model as being the DNA code of a company that outlines five principles (Creativity,

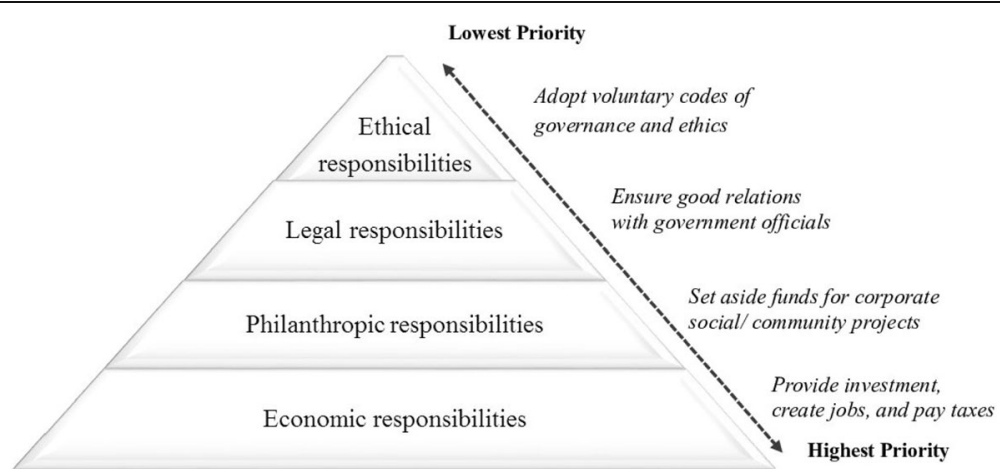

Fig. 7 Drivers of the CSR pyramid model for developing countries. Source: Visser (2006, p.489) 
Scalability, Responsiveness, Glocality, and Circularity). This represents an effort to design an inherently sustainable and responsible business model, supported by a reformed financial and economic system. However, the emphasis is clearly on the profit motive to the detriment of initiatives related to environmental conservation. And it remains a solely normative approach that does not provide companies with a practical tool which allows them to implement CSR effectively (Claydon, 2011). Claydon (2011) developed his "consumer-driven corporate responsibility model" which states that in order to be profitable, the consumer demand for CSR must be satisfied. Hence the company adopts CSR, which, in turn, attracts more customers and other stakeholders who duly achieve more profits. According to this model, the company does not have to choose between being profitable or socially responsible, but it may and indeed should focus on both objectives at the same time because one depends on the other. This is seen as a very simple model that does not explain complex interrelations between business, society, and the environment. It ignores issues concerning companies' accountability, and likewise omits to consider the institutional conditions of CSR implementation. Nalband and Kelabi (2014) developed their CSR-Universal model after re-visiting Carroll's (1991) CSR Pyramid, and including generic elements of beliefs, values, and assumptions. Their model signifies legal responsibility as the main obligation, and postulates that the majority and/or an influential group in a company have the 'final say' as to what becomes the key responsibility of the company when a conflict in choice among various responsibilities occurs. In this case, the model does not specifically address how to tackle an 'environmental issue' despite the addition of the new elements (i.e. beliefs, values, and assumptions).

In summing up the various contributions to the CSR debate, all of the previously mentioned models have their unquestionable significance. These models are useful as they bring a wider understanding of the CSR concept. However, they have shortcomings which render them ineffective, and raise strong criticism of the CSR concept itself. Indeed, the majority of CSR models reviewed in this paper, have tried to describe the CSR theoretical construct and thus do not consider the relationship between basic economic conditions and CSR behaviour.

\section{New international pyramid model for the CSR}

It has been shown that the criticisms of Carroll's CSR Pyramid model have generated many attempts to construct a model that can genuinely be appropriate for other countries than America, and for the conditions faced by smaller businesses. One such attempt of worth, was that by Visser, since his model's use of the stakeholder approach may ultimately widen the initially- outlined scope of responsibilities. The difference between the two models is not only in the order of priority or emphasis between the categories of responsibilities, but also in the scope of responsibilities. However, this addition still does not address all the issues. As for the other models briefly mentioned, it is clear that they are limited in their additions/changes and do not present a comprehensive answer. In this study, therefore, the categories proposed by both Carroll and Visser in their models, as social responsibilities, are followed with some modifications, in an effort to devise a new pyramid that can be transferred to all environments. The four CSR responsibilities within this new pyramid are economic, glocal, legal and ethical, and philanthropic. The glocal drivers of CSR, which represent a new addition, include: environmental conditions, socio-cultural matters, users of technology, and political rights. These are the conditions which do vary from one place to another and change over time due to the active or passive behaviour among managers, leaders and power structure in society. Given the argument by Antal et al. (2009, p.285) that "the relations between business and society are defined in different ways according to historical, [cultural, political] socio-economic and legal context and the powers of the relevant actors", it seems necessary to acknowledge this in the new pyramid.

Hence, the identification of company responsibilities in respect of their internal and external economic and business behaviour is made within the International Pyramid model of CSR devised by the author. Attention to such responsibilities is suggested as being the most direct way to improve the prospects of communities, and simultaneously deliver goods and services which result in profit for shareholders, and revenues (through taxes) for governments. Thus, the International Pyramid is one that accepts the role of all shareholders and managers in discharging social responsibilities. However, what it means to be socially responsible, must be clarified, and from the definitions expressed already it can be seen that this embodies a continuing commitment by business to behave legally, ethically and philanthropically, while contributing to economic development globally. This implies attending to the environmental conditions of society as a whole, considering socio-cultural matters, users of technology, and the prevailing political rights enjoyed by individuals. Figure 8 illustrates the newly-developed International Pyramid of CSR, and thereafter each element is discussed.

In other words, the tiers of responsibility are flexible. In the model illustrated, the philanthropic responsibilities are located at the top of the International Pyramid of CSR, but they could change either tier two or three, depending upon the context. Likewise, the glocal responsibilities placed on tier two, could switch to assume the top place in the pyramid, whilst the legal and ethical responsibilities 


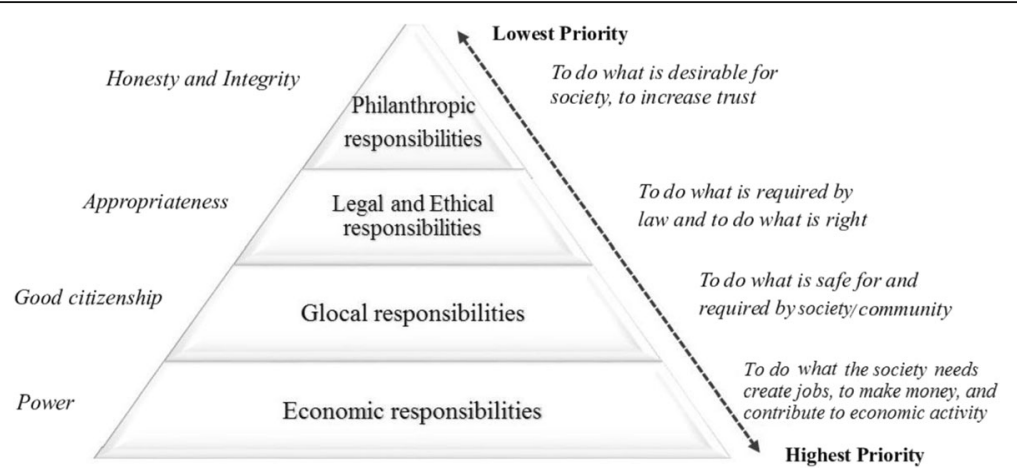

Fig. 8 International Pyramid Model of CSR Source: Developed by the author, 2016

could be represented by either the third or the fourth tier or perhaps could be the highest CSR priority, in order to be consistent with company direction. Clearly, these layers of responsibility are essential, but as suggested by the model, the emphasis on each can and indeed, should change according to circumstance. The only type of responsibility not enjoying this flexibility is the economic responsibility since this is the reason for a company being in existence in the first place, and it is through this that a national economy is boosted via revenues, and employment and investment opportunities. Perhaps economic responsibility assumed as primary could change with either tier two or three - glocal, and legal and ethical responsibilities - if a change in attitudes over time were to occur as a result of the differences between the types of CSR activity enacted in response to countries' very different priorities, norms, and values during their different periods of economic development. On the other hand, it might be argued that whilst there might be less awareness and/or practice of economic responsibilities in nations, this by no means indicates that economic responsibilities are not as important as other responsibilities.

The key question is: what does this add to the explanatory value if the tier order can be one way - or another? Does the concept win or lose? Although the pyramid can be perceived as a static snapshot of the tiers of responsibility, it is nonetheless intended to be viewed as a flexible tool embodying a dynamic tension which allows the framework to adapt to enable a focus both on the present and the future. Clearly, corporate responsibilities have evolved over time as companies themselves have changed in relation to the business environment. Half a century ago, there was greatly stability in the business environment whereas today companies find themselves in much more dynamic situations, and this means that they have had to become more mature in the way they deal with these. In respect of corporate responsibility issues, the public (society) are expecting more, and business itself gives more. Indeed, CSR imperatives are now so pervasive that companies now have $\mathrm{CR}$ officers dedicated to managing this aspect of their existence, and operating as professionals in managing the companies' relationships with all their stakeholders. The International Pyramid of CSR, like the concept, has failed. Success or failure should be measured in terms of a company's net impact on the environment, and if there is to be any reversal of many of the world's most pressing problems, e.g., social, environmental, local legislative, ethical trends and so on, a different kind of CSR is needed. It is easy to agree that we ought to be doing something good, and that we should contribute to doing 'the right thing', and there is evidence that the business community globally has been rapidly adopting CSR practices in both the developed and developing regions. We can see that corporations have learned to adapt to changes in economy, technology and politics. But they have also adapted to social change as public expectation has, over years and decades, experienced the modern corporation; which has been adoptable. The public have seen what it is and known what they have to do, and have done it. Consequently, the International Pyramid developed in this research and reported here, is built in a fashion that reflects the fundamental roles played and expected by business, which are seen as being to invest in society/community projects such that business implicitly concerns itself with the future.

The pyramid becomes workable in different countries, through its recognition that what is at its apex can change according to the national and/or smaller business context. Although no comparative empirical study has been conducted, it is speculatively argued that the order of the layers in different regions of the global, situational, and organisational contexts (if taken as an indicator of relative emphasis assigned to various responsibilities) differs from the order in the classic pyramids advanced by both Carroll, and Visser. In the International Pyramid, economic responsibilities still attract the most emphasis, meaning that the only way companies or businesses can gain respect in this area is to do something which no one else can do. Business should not try to solve all societal 
issues. Rather, it should concentrate on fairly tangible business operations, in what is referred to as the corporate competitive context. In behaving this way, business needs to reconcile the challenges from shareholders and activists at the same time. Of the other three domains in the pyramid, glocal is given second highest priority, followed by legal and ethical, then philanthropic responsibilities. This helps to eliminate the inherent assumption of a hierarchical relationship among the domains which some have perceived in Carroll's pyramidal depiction of CSR. The broadening of the domain descriptions provides a more complete construct by which to better classify corporate activities. This is illustrated in Fig. 8. It is argued that this model provides a more appropriate means and theoretical framework by which to categorise CSR activities. As corporate managers and business students reflect on corporate actions and where they should be classified within the International Pyramid model, an improved understanding of the relationship between business and society and more specifically between economics, glocal, legal and ethics, and philanthropic, should occur, and the various constructs should become more refined. Each of the CSR principles is now briefly reviewed.

\section{CSR principle 1: economic responsibilities}

Economic responsibilities are the first and foremost concern of CSR since the company must receive income and make profit to survive. Without the power to make and maximise a profit, a business can hardly contribute in the area of social responsibility. For instance, many developing countries suffer from a shortage of foreign direct investment and short-term profitability that may affect their business within their target markets, their total sales, unemployment rates, and interest rates. If a company does not make money, it will not survive, employees will lose their jobs, less money will be available for those individuals to spend in the local economy, and ultimately the company will not be empowered to discharge its overall social responsibilities. However, businesses in some areas of the world are not driven by money. Certainly in Muslim countries, organisations are guided by philanthropic principles dictated by Islam, and focusing on "falah" which translates into the genuine well-being of others (Darrag and E-Bassiouny 2013). Dusuki and Abdullah (2007) have indicated that organisations can achieve "falah" if they "assume their roles and responsibilities as servants and vice-gerents of God in all situations" (p. 33).

So, before a company thinks about being a good corporate citizen, it first needs to make sure that it can be profitable and is able to share benefits from its business activities within society by responding to society's interests, what it wants and needs. According to the Green Report by the European Commission (2001, p.12), "[c]ompanies contribute to their communities, especially the local ones, by providing jobs, wages and benefits and tax revenues. On the other hand, companies depend on the health, stability, and prosperity of the communities in which they operate. For instance, they recruit the majority of their employees from the local labour markets, and therefore have a direct interest in the local availability of the skills they need". Elkington (1999), Visser and Sunter (2002), and Visser (2006) argue that despite the attempt in Carroll's CSR Pyramid to establish an umbrella concept for the relationship between business and society, the model fails to consider the inter-related economic, social and environmental aspects that impact upon CSR. Furthermore, there is still a need to balance the interests of the organisation and its stakeholders.

The International Pyramid is in agreement with the models proposed by Carroll (1991), Pinkston and Carroll (1994), Edmondson and Carroll (1999) and Visser (2006) in suggesting that in developed and developing nations, economic responsibilities can be considered as the primary tier if need be, as certainly in Africa and the Middle East, Central and Eastern Europe, South and Latin America, and Asian countries, the economies are weak and much driven by government intervention. Additionally, for the same reasons, the poor socioeconomic conditions demanding for example, poverty alleviation, education, health, and infrastructure development, etc. have been considered the most important issues in communities. Research by Pedersen (2010) and Baden (2016) suggests that ethical responsibilities should come before economic responsibilities, yet Carroll's Pyramid of CSR, arguing that profit refers to "economic responsibilities" that are more pressing than legal and ethical responsibilities, points to the unwelcome outcome that social welfare will be sacrificed for economic ends.

Hence, the concept of sustainable economic responsibilities is now acknowledged in the International Pyramid model of CSR by introducing the regional and national economic value-added performance together with valuecreating investments as key issues. These are priorities for any environment at any given point of time, requiring CSR-related actions to develop relationships between the organisation and all its stakeholders, such that the latter are benefitted. Indeed there are important reasons why a consideration of the economic responsibility impact of business should come first. Arguably, business exists to serve society, and profit is just one of several other useful indicators. That is to say, responsibility is not only viewed through economic indicators, but also through ecological and social performance which implies looking beyond economic functions to community functions. Hence, the practical cost/benefit calculation should not be the only factor used when determining how much and to whom one should contribute. 


\section{CSR principle 2: glocal responsibilities}

According to The Oxford Dictionary of New Words, the term 'glocal' and the process noun 'glocalisation' are "formed by telescoping global and local to make a blend". Also, according to the Dictionary that idea has been modelled on the Japanese dockakuka, which is derived from dochaku "living on one's own land", and which was adopted in Japanese culture and business as a way of describing a global outlook adapted to local conditions during the 1980s. By the beginning of the 1990s, this had become one of the main marketing buzzwords in the West. Visser aptly discusses CSR in the global context when he elaborates on CSR in different regions of the world, stating that "CSR is the same the world over". Among the (glocal "global + local") drivers of CSR, he suggests that socio-economic priorities, cultural tradition, political reform, governance gaps, and crisis response are among the most important (Visser 2011, p. 269).

In CSR in different contexts, the idea of "think globally, act locally" or "think global, act local" recognises that most relevant CSR issues are presented as dilemmas rather than as easy choices to make, and that such dilemmas must be properly managed and averted if business is to be conducted in a responsible and sustainable way. Kemp (2001) has argued that this has implications for social and political rights and responsibilities, and that business ethics are integral to political democracy and economic stability, both of which are promoted by good corporate governance (Rousseau et al. 2008). That said, socio-political issues are generally more prevalent in the advent of new governments, and that technology companies have played a significant role both in supporting and constraining pro-democracy movements in recent times (Crane et al., 2013), thus leading to national drivers of political reform. Cultural tradition is seen as a national driver of CSR since CSR is often derived from "deep-rooted indigenous cultural traditions of philanthropy, business ethics and community embeddedness" (Visser, 2008, p.481).

The glocal responsibilities are located in the second tier of the International Pyramid model of CSR, representing the obligation of corporate decision makers to engage in actions which protect and improve the environmental conditions of society as a whole, whilst also acknowledging socio-cultural aspects, users of technology, and the nature of political rights. This imperative stresses that company decisions should not only be made with reference to financial factors such as profits or dividends, but also by considering social and environmental consequences, and the potential for long-term support technology transfer to help in building physical and institutional infrastructure. In this model, we include technology responsibilities in order to identify how the technology sector can best give back to society. A study conducted by Lorenzo et al. (2009) states that the fact of belonging to the technology and telecommunications sector has a positive but not significant influence on the dissemination of CSR activities in the community. In addition, the movement of a company has a high social impact when it operates in Information and Communications Technology (ICT) (Luna Sotorrío and Fernández Sánchez, 2010). Companies located in technology parks are more innovative and their work is directly related to two of the three dimensions of CSR "economic and social community". They can generate a network of co-operation between technology companies, which can increase the ability to attract, retain and motivate staff and access to new knowledge and information, which could increase companies' performance and competitiveness (Hernández and Sánchez, 2012). Green information technology (IT) also known as an environmental technology, helps society to reduce the consumption of energy while others help in recycling, waste management, water purification, renewable energy, and sewage treatment. Thus, it is possible to use the technology sector's greatest ability to address a common weakness of social sector organisations. For example, Asian countries' websites are still not widely used for business communications, because the IT facilities remain in the introductory stage and internet usage is low (Chapple and Moon, 2005; Rotchanakitumnuai and Speece, 2003), but at the same time there is a global movement towards the standardisation of CSR initiatives (Edmondson and Carroll 1999; Burton et al., 2000; Visser, 2008), which has led to great change in the world, characterised by diverse demographic dynamics and political developments. For instance, the Egyptian revolution of the Arab Spring, was widely lauded as the first wave of "Facebook revolutions" and one of its more prominent and influential decisionmakers was a Google executive (Smith, 2012). At the same time, studies have suggested that companies continue to exercise political pressure by affecting regulatory changes in relation to social and environmental issues (McWilliams et al., 2002; Child and Tsai, 2005; den Hond et al., 2014), as political issues and CSR are increasingly intertwined. A further study by Ungericht and Hirt (2010) argues that the political role of CSR has emerged due to globalisation and the 'responsibility vacuum' created, while Whelan (2012) argues that "political" CSR should be conceived as one potential form of globalisation, and not as a consequence of globalisation. It would appear that how managers conceptualise the relationship between political and social/environmental issues, or ponder on how to use the effectiveness of business processes is important, as it may lead to a richer understanding of the actual political influence of companies, the companies' role within global governance or the natural resources and effectiveness of new hybrid forms of social and environmental regulations. 
The International Pyramid model of CSR, in defining 'glocal' responsibilities, focuses on the company understanding of social responsibilities as they present themselves at the specific time and in the specific culture and country where companies are operating. Hence, it takes into account the local institutional environment in developed, developing, and emerging/transitional economies. Visser et al. (2007) suggest that different cultures and sub-cultures not only give different nuances to the meaning of each component, but may also assign different relative importance and challenges. The scope of different cultural and sub-cultural responsibilities are the major variations, and the level of development of a country may be a key indicator (Burton et al., 2000; Chapple and Moon, 2005), as also might the religion of the country, which can vary e.g., country or community has different drivers coming from its culture, and the environmental obligations associated with CSR vary. Environmental responsibilities, defined as "doing what is safe for the environment" are clearly identified as a separate type of necessary responsibility. Carroll's original pyramid, whilst striving for universality, does not show itself when tested empirically, to be able to explicitly point to where companies' environmental responsibilities lie, and which priorities they ought to follow. For Visser (2008) corporate responsibilities for the natural environment are a transversal issue as he mentions the environment in reference to legal, ethical, and philanthropic responsibilities. The model suggests that environmental responsibilities should be a component of CSR rather than environmental issues because such issues do not exactly relate to economic responsibilities and should not be placed within philanthropic responsibilities or ethical responsibilities, as this component of CSR is often seen as voluntary rather than mandatory. Thus, environmental responsibilities are seen as one of the important components of social responsibilities of social community. Within the International Pyramid Model of CSR, glocal responsibilities are separate from philanthropic and ethical obligations on the grounds that essentially, these latter concerns are purely voluntary, being undertaken for what companies perceive to be the good of society. Clearly, this leaves the activities involved entirely to the company, in other words the decisions are subjective. The concept of 'glocal' has however, come to embody more than a subjective and voluntary appreciation of what might be good for the community, as over the last decade, it has become recognised that glocal responsibility is a legitimate and necessary component of corporate responsibility that is expected by society. Hence, there is a sense of duty attached to it, whereas the very word 'philanthropy' implies benevolence, charity, and in no way a requirement. Returning to the idea that it matters what management and companies do, as well as what they achieve, it can be appreciated that more clarity of the glocal responsibilities will promote higher standards of behaviour. And in consequence, the glocal responsibility will be perceived as a 'required' obligation to be fulfilled by companies. This responsibility encompasses notions of good citizenship, of contributing to the human, reputational, financial, technical, and physical resources of the community of which it is a part, to support its development. Like everyone else, corporate citizens should balance their rights and responsibilities in the aim of creating a better society, which in turn implies a better environment for doing business. The International Pyramid suggests that words should be supported by action. Good glocal conduct can be encouraged by addressing four specific dimensions of organisational activity, these being: environmental, sociocultural, technological, and political. Each of these can make an important contribution to an integrated 'glocal' responsibilities programme as a fundamental aspect of the CSR Pyramid, in order to achieve business goals.

\section{CSR principle 3: legal and ethical responsibilities}

The International Pyramid model of CSR suggests a merger of the legal and ethical responsibilities, and that these are accorded the third priority. These responsibilities could, therefore, range from regulations relating to the environment, the employment of labour, the use of technology, to issues relating to countries which may not be considered suitable for trading with. However, when a company is implementing a new business ethics policy, it may find that this is the most significant responsibility it has to discharge, and that the issue of trading ethically as a component of its sustainable development strategy, extends beyond legislative compliance. This is an interesting area for debate since in sourcing suppliers with good credentials; a company may be doing more than is legally required because its owners believe it is the right thing to do, and not because they have an obligation to behave in this way. This approach signals decisions and actions that show concern for what its stakeholders consider fair and just, and despite not being mandated by government, it emerges as a legitimate aspect of company goals. That said, the establishment of laws and regulations to guarantee a minimum level of ethical activity is necessary since not all companies/individuals possess such values, and there must be a means by which governments can take corrective action by punishing organisations, and employees who do not comply with company standards and by rewarding those who do, to ensure compliance with government policy, particularly in emerging/transitional economies. Most of the literature accepts that many ethical stances taken by corporations are beyond legal requirements and are adopted in recognition of a belief that businesses have ethical responsibilities 
towards society (Jones, 1980; Manakkalathil and Rudolf, 1995; Carroll, 1999; McWilliams and Siegel, 2001; Kok et al., 2001; Oppewal et al., 2006). Visser (2008) suggests that the interpretation of legal responsibilities has an emphasis on ensuring "good relations with government officials", and centres on the adoption of voluntary codes of ethics. Carroll's model, on the other hand, focuses on obeying the law, suggesting that companies have more than the wider "obligation to do what is right, just and fair" and do indeed have legal responsibilities to "obey the law". In the Islamic context, ethical responsibility is considered an important responsibility; the term "Khuluq" which means "character, nature, and disposition", appears in the Holy Quran and the prophet Mohamed was described as being of "great moral character" (Quran: 68: 4). The concept of good values is described in the Holy Quran with many terms such as: al-adl (justice), al-haqq (truth and right), al-khayr (goodness), al-ma'ruf (known and approved), al-birr (righteousness), al-salihat (pious action), al-qisr and al-iqsat (equity), and al-taqwa (piety) (Rizk, 2008; Abuznaid, 2009) as these are important when dealing with others, and this should be visible in business activities (Abuznaid 2009; Siwar and Hossain, 2009).

The International Pyramid allows for the legal and ethical responsibilities to assume greater or lesser importance, being represented by either the third or the fourth tier, or even climbing to become the highest CSR priority. This degree of flexibility follows from Visser's (2006) suggestion that ethical and legal responsibilities in Africa remain the lowest CSR priorities since there are poorlydeveloped legal infrastructures in African countries. Similarly, ethical responsibilities are claimed to be a higher priority in Europe than in the US (Crane and Matten 2007a, 2007b). Furthermore, the fact that in Carroll (1991) Pyramid Model, the legal responsibilities are located in the second row and follow by ethical responsibilities, indicates the belief that US companies are more interested in discharging their legal and ethical responsibilities rather than the discretionary ones. Later research, however, suggests that legal and ethical responsibilities are more primary (Sachs and Ruehle, 2009; Pedersen, 2010, Baden, 2016), and certainly, French and German consumers tended to rate legal and ethical responsibilities of primary importance (Maignan, 2001).

The International Pyramid model of CSR suggests that legal and ethical responsibilities are the focus of social resistance to many commercial projects in developed, developing, and emerging/transitional economies, and may, in fact, be the deciding factor in debating the contribution of the economic, business, government, and civil society collaboration to sustainable development. The International Pyramid allows for the legal and ethical responsibilities to be considered in a different way, such that the business can work to meet the lower-level responsibilities that obligate it to shareholders and the law, and can simultaneously move on to the higher-level responsibilities of the company that have long-term future benefit for society. This gets around the problem found in some countries by the fact that the legal and ethical environment is not always sufficiently comprehensive and hence, enforcement may be weakened. The outcome of this lack of development is that certain environmental responsibilities may not be properly covered within legal and ethical responsibilities. Consequently, the main difference between philanthropic responsibilities, and legal and ethical responsibilities, can be seen in what is mandated and what is not. Regulatory and enforcement issues are concerned with legal and even some ethical responsibilities, while philanthropic components are not.

\section{CSR principle 4: philanthropic responsibilities}

It can thus be seen that philanthropic responsibility is actually not an enforceable responsibility at all, but rather one that involves purely discretionary activities. The word 'philanthropy' comes from the Greek word philanthropia "philia, friendship or phileo, love + anthropos, human" and means benevolence, kind-heartedness, humane feeling, kindliness, courtesy, or gods' love for humans (Liddell and Scott, 1940, s.w. philia; philanthropia). When used in the context of corporate business, it refers to a company's tradition of charitable (or voluntary) behaviour, which embodies the idea of giving something back to society. This notion of giving back to society involves corporate business recognising its responsibilities towards employees, suppliers, clients, stockholders, and the general internal environment, and in supporting humanitarian action to achieve social aims through investment in the protection of the internal and external community. Such an outlook implies that companies voluntarily contribute to a better society and build trust with their communities to promote human welfare or goodwill. HIV/AIDS is a case in point, where the response by business is essentially philanthropic, since it is not an occupational disease, but clearly that type of response is in companies' own medium- to long-term economic interest. Hence, what is done is entirely at the discretion of organisations. This is seen as a problem by Levy (2002), who suggests that philanthropic activity is vulnerable to people's sympathies and economic circumstances, which are susceptible to fluctuations, and that there is a constant reduction in such activity.

Within the International Pyramid model of CSR, philanthropy is given the lowest priority since the discretionary nature of such responsibilities means that most companies will attend to them after having ensured that they have discharged the others. Particularly, in developing countries, it is not feasible to suggest that all companies have the means to consider philanthropical activities. Clearly, 
one of the most visible ways in which a business can help society is through corporate philanthropy, but managers of companies have no right to make such decisions about how profits can be used as the money does not belong to them. Consequently, it is the stockholders who are involved with philanthropical decisions as it is their money that underpins all actions ensuing from them.

The International Pyramid is in agreement with the model proposed by Visser (2006) in that the philanthropic aspect of CSR could be placed on the second tier if needed, as it is required in Muslim countries for companies to be directed by religious imperatives, and thereby recognise their philanthropic responsibility as the most direct way of improving the prospects of local communities. Hence, the concept of philanthropy is embedded in business organisations in these countries, being seen as a vehicle for alleviating poverty, disease, and hunger, and for providing a better education for children, equal opportunities for women, better community support, improved working conditions, and a healthier environment. Islamic principles encourage all people to give in charity through the practice of Zakat (obligatory charity) and Sadaqah (voluntary charity). Zakat is the fifth pillar of Islam, and is a specified percentage of amount/quantity taken from specific sources of wealth (i.e., livestock, savings, trade goods, crops, and minerals) and given to the poor and those in need. Evidence for this obligation is found in the Quran, where God says, "[...] And perform the prayer, and give Zakat" (Quran 2:43, 2:100); and "Take, [O, Muhammad], from their wealth a charity by which you purify them and cause them increase" (Quran 9:103). In addition, the categories of eligible recipients for Zakat are mentioned in the Quran, as God says, "Alms are only for the poor and the needy, and those who collect them [zakat], whose hearts are to be reconciled, captives, debtors, in the cause of Allah, and wayfarers" (Quran 9:60). Muslims believe that Zakat attracts God's special blessing and their wealth will be multiplied after they have paid Zakat, in which respect God says, "Any charity you give will be repaid to you, without the least in justice" (Quran 2:272). Zakat, as mentioned above does not necessarily have to be paid in money but can be seen in the form of agricultural products, specifically as food for the hungry. God says, "O you who believe, you shall give to charity from the good things you earn, and from what we have produced for you from the earth. Do not pick out the bad therein to give away, when you yourselves do not accept it unless your eyes are closed. You should know that Allah is Rich (Free of all wants), and Praiseworthy" (Quran, 2:267). Therefore, Zakat is obligatory (about $2.5 \%$ of one's savings) but only if it can be afforded. And if it cannot then one should try to give people a smile, which is an act of charity, it will count as 10 good deeds or more depending upon the intention. How much one gives after $2.5 \%$ is a matter of choice.
Sadaqah on the other hand, is the worship of Allah by giving money voluntarily and being directed to do that via Shari'ah. The main restriction placed on this type of charity is that it cannot be intended to facilitate anything that Islamic law deems unlawful. In contrast to Zakat, there is no specific time or amount required by the Quran for giving Sadaqah. Throughout the Quran, Allah encourages Muslims to give Sadaqah to the needy whenever they can, by stressing the generous multiplication of rewards for those who freely give of their assets and time. God says, "The example of those who spend their wealth in the way of Allah is like a seed [of grain] which grows seven spikes; in each spike is a hundred grains. And Allah multiplies [His reward] for whom He wills. And Allah is allEncompassing and Knowing" (Quran 2:261).

Although Sadaqah should be given to please God by helping someone in need. God says, "O you who believe! Do not render in vain your Sadaqah (charity) by reminders of your generosity or by injury, like him who spends his wealth to be seen of men, and he does not believe in Allah, nor in the Last Day. His likeness is the likeness of a smooth rock on which is a little dust; on it falls heavy rain which leaves it bare. They are not able to do anything with what they have earned. And Allah does not guide the disbelieving people" (Quran 2:264). God says, "Those who spend their wealth in the Cause of Allah, and do not follow up their gifts with reminders of their generosity or with injury, their reward is with their Lord. On them shall be no fear, nor shall they grieve" (Quran 2:262). God says, "So whoever does good spontaneously, it is better for him" (Quran 2:184).

For this reason, the Quran encourages Muslims to give their Sadaqah anonymously to ensure that the Sadaqah is made with the pure intention of helping the needy and pleasing God rather than to attract the attention of others. God says, "If you declare your charities, they are still good. But if you keep them anonymous, and give them to the poor, it is better for you, and remits more of your sins. GOD is fully Cognizant of everything you do" (Quran 2:271). Similarly, the Prophet Muhammad (P) said: "Seven people Allah will shade in his shade on the day when there is no shade except his". Among the seven he mentioned was "a man who gave something in charity secretly such that his left hand did not know what his right hand has given". However, Sadaqah does not have to be a financial gift. If a Muslim does not have enough money to give a financial Sadaqah, he or she can give a Sadaqah by helping others or simply by refraining from evil doing. Prophet Muhammad (P) said, "All of you are shepherds and each of you is responsible for his flock" Also he pointed out "The believers in their mutual love, mercy, and compassion are like one body: if one complained, the rest of the body develops a fever". Muslim charities give to non-Muslims too. There is no 
obligation to restrict Sadaqah to Muslims; therefore, it can be given to Christians or Jews as well. Hence, philanthropic concepts from the Islamic perspective are similar to the existing understanding of philanthropy in the West which is to support society.

However, despite these religious directives to engage in philanthropic activities, there is low CSR practice in terms of philanthropy in poor countries of the developing world, for the reasons already mentioned. Our model also suggests that there is social responsibility lying within company terms and rules. The first rule deals with how much to spend in charity; is it permissible for the chairman of the board to spend a third in charity? Doing so, violates the law which states that it is not permissible to donate more than $5 \%$ of the profits, as there are social responsibilities placed upon organisations also, and there has to be a check on the associated data records and balance sheet. Also, the operating budget of the charity organisation should be considered. Thus, if it is a new organisation, it is allowed to spend on its operating budget up to $40 \%$; however, if it is an old one, then the donation percentage ranges from $5 \%$ to $12 \%$ as for an operating budget. Moreover, if the percentage exceeds this limit, then this organisation should not be given in charity. The best type of charity is not money unless the organisation is a financial institution. Rather, an organisation should give in charity from what it produces. For instance, an IT company should give in charity some of its IT products, and the construction companies should do the same. The second rule, states that the continuous charity is better than the discontinuous charity. Waqf in Islamic is a good proof of this.

Hence, it is apparent from the flexibility within the International Pyramid Model of CSR that philanthropical responsibility can move up or down the pyramid depending upon the cultural environment, and that where there is no imperative from religious law to prioritise this, or where countries are experiencing very challenging times, it can adopt the lowest priority since there is no legal compulsion to effectively give money away.

\section{Conclusions}

Our goal was not to write the extensive history of the concept which could be obtained from other sources but to sketch what elements might be included if it were written, and to identify at least some of the interesting/ useful factors that might contribute to such an undertaking. Specifically, we focus on the theoretical framework underpinning CSR. CSR has been robust over the past 50 years or so, and has continued to expand in support, adaptation and applications by businesses and academics who have also shown increased interest in the topic. In addressing contributions to the CSR debate, four major comments can be made about the different models constructed to date, listed as follows: (1) most models show a concern for the philanthropic aspects of CSR. They accept the notion that economic considerations do as a matter of fact preside over the environment and that opportunities must be pursued to prevent pollution (Hendry and Vasilind, 2005), thereby implying that social responsibility will be embraced if the idea of going green has economic value (Aras and Crowther, 2009; Kanji and Chopra 2010; Visser, 2010); (2) most models focus on the economic motive as the primary priority of a business (Hendry and Vasilind, 2005); (3) most of the study findings are based on survey data gained from the managers or owners of businesses to identify the factors that should be included in any CSR model adopted (Elkington, 1999; Kanji and Chopra 2010) without considering how CSR activities can be integrated as part of a green process; (4) most models are founded on the fundamentals of social ethics, profit motive, governance, cultural freedom, safety and health, accountability, transparency, and competitiveness which are proposed to have overlapping functions (Friedman, 1970; Marsden and Andriof, 1998; Elkington, 1999; Kennedy, 2001; Meehan et al., 2006; Ketola, 2008; Aras and Crowther, 2009; Kanji and Chopra 2010; Kanji and Chopra, 2010; Visser, 2010), without focusing exclusively on specific elements such as environmental protection.

Given that the development of Carrolls' Pyramid Model of CSR occurred in the West, it has not been effective as an analytical tool for the developing world. However, Visser's attempt to remedy this has also been ineffective in providing a comprehensive description of CSR responsibilities. Hence, after reviewing these major contributions, together with several minor ones introduced to try to remedy the deficiencies identified in the two models mentioned, the author has produced the International Pyramid Model of CSR, which is seen to bring the following benefits:

1. The model is devised after revisiting both Carroll's and Visser's models which are well-known and understood, and therefore, the concepts involved in it are well articulated, and it is easy for its audience to understand.

2. The model is flexible in respect of the tiers and scope of CSR responsibility, and therefore, can provide solutions for a range of different circumstances, both national and commercial.

3. The model acknowledges a transition in focus from the early concept of CSR which focused on economic responsibilities to one that acknowledges glocal, legal and ethical, and philanthropic responsibilities, and thus allows a holistic approach to social responsibility practices in different countries. 
4. The model acknowledges the important role of economic responsibility, suggesting that good management should enable greater economic prosperity to be able to generate an increase in capital spending, create jobs, contribute towards education, support the development of human resources, and generally invest more in society in general.

5. The inclusion of glocal responsibilities in the second row of the International Pyramid emphasises the link between the global and the glocal, and encourages CSR activities to look beyond the immediate population to the wider population of the country concerned, and even beyond that to the global community as a means of identifying worthwhile social goals and remedying social concerns.

6. The visual depiction of legal and ethical responsibilities shows them as being inter-related, as ethical issues are often a driving force behind the creation of laws and regulations.

This model, is expected to bring sophisticated analysis techniques that facilitate solutions to societal problems in many different nations. It is recommended that this all-encompassing model of CSR be tested in a number of diverse settings to establish how effective it can be in practice, and hence to verify its usefulness. Theoretically, it can be seen to address the criticisms made of earlier models and can, therefore, be expected to meet with success in the practical situation, wherever, and whatever that might be. We encourage further research and application of the ideas in different societies whether in developed or less developed societies, in market economies, or in any other societal orders.

\section{Note}

1. We use the terms "developed" and "developing" (and in respect of the latter also "emerging" and "transitional") for convenience, as these terms are widely used and their meaning generally understood, but we do so self-consciously, recognising that they are both complex and contested and constructed from a particular, northern/western perspective.

\section{Acknowledgments}

We would like to thank the anonymous reviewers and Editor in Chief for their useful comments on earlier versions of this paper.

\section{Competing interests}

The authors declare that they have no competing interests.

\section{Publisher's Note}

Springer Nature remains neutral with regard to jurisdictional claims in published maps and institutional affiliations.
Received: 3 February 2017 Accepted: 15 May 2017

Published online: 08 June 2017

\section{References}

Abuznaid, S. (2009). Business ethics in Islam: The glaring gap in practice. International Journal of Islamic and Middle Eastern Finance and Management, 2(4), 278-288.

Ackerman, R. W. (1973). How company responds to social demands. Harvard University Review, 51(4), 88-98.

Ackerman, R.W., \& Bauer, R.A. (1976). Corporate social responsiveness. Reston: Reston Publishing Company.

Antal, A. B., Oppen, M., \& Sobczak, A. (2009). (Re) discovering the social responsibility of business in Germany. Journal of Business Ethics, 89(3), 285-301.

Aras, G., \& Crowther, D. (2009). The durable corporation: Strategies for sustainable development. Aldershot: Gower.

Aupperle, K.E., Carroll, A.B., \& Hatfield, J.D. (1983). Instrument development and application in corporate social responsibility. Academy of Management Proceedings. 369-373. doi:10.5465/AMBPP.1983.4976378.

Aupperle, K. E., Carroll, A. B., \& Hatfield, J. D. (1985). An empirical examination of the relationship between corporate social responsibility and profitability. Academy of Management Journal, 28(2), 446-463.

Baden, D. (2016). A reconstruction of Carroll's pyramid of corporate social responsibility for the $21^{\text {st }}$ century. International Journal of Corporate Social Responsibility, 1(8), 1-15. doi:10.1186/s40991-016-0008-2.

Baughn, C., Bodie, N., \& McIntosh, J. (2007). Corporate Social and environmental responsibility in Asian countries and other geographical regions. Corporate Social Responsibility and Environmental Management, 14(4), 189-205.

Beurden, P., \& Gossling, T. (2008). The worth of values - a literature review on the relation between corporate social and financial performance. Journal of Business Ethics, 82(2), 407-424

Bhattacharya, C. B., \& Sen, S. (2004). Doing better at doing good: when, why, and how consumers respond to corporate social initiatives. California Management Review, 47(1), 9-24.

Bowen, H. (1953). Social responsibilities of the businessman. New York: Harper \& Row.

Burton, B. K., Farh, J. L., \& Hegarty, W. H. (2000). A cross-cultural comparison of corporate social responsibility orientation: Hong Kong vs. United States students. Teaching Business Ethics, 4(2), 151-167.

Carroll, A. B. (1979). A three-dimensional conceptual model of corporate social performance. Academy of Management Review, 4, 497-505.

Carroll, A. B. (1991). The pyramid of corporate social responsibility: Toward the moral management of organizational stakeholders. Business Horizons, 34(4), 39-48.

Carroll, A. B. (1999). Corporate social responsibility: Evolution of a definitional construct. Business and Society, 38, 268-95.

Carroll, A. B. (2008). A history of corporate social responsibility: concepts and practices. In A. Crane, A. McWilliams, D. Matten, J. Moon, \& D. S. Siegel (Eds.), The Oxford Handbook of Corporate Social Responsibility (pp. 19-46). Oxford: Oxford University Press.

Carroll, A. B. (2015). Corporate social responsibility: The centerpiece of competing and complimentary frameworks. Organizational Dynamics, 44, 87-96.

Carroll, A. B. (2016). Carroll's pyramid of CSR: Taking another look. International Journal of Corporate Social Responsibility, 1(3), 1-8.

Carroll, A. B., \& Shabana, K. M. (2010). The business cases for corporate social responsibility: A review of concepts, research and practice. International Journal of Management Reviews, 12, 85-105.

CED. (1971). Social responsibility of business corporations. New York: Committee for Economic Development.

Chapple, W., \& Moon, J. (2005). Corporate social responsibility in Asia: A sevencountry study of CSR web site reporting. Business \& Society, 44(4), 415-441.

Child, J., \& Tsai, T. (2005). The dynamic between firms' environmental strategies and institutional constraints in emerging economies: Evidence from China and Taiwan. Journal of Management Studies, 42(1), 95-125. doi:10.1111/j.14676486.2005.00490.x

Clark, J. M. (1916). The changing basis of economic responsibility. Journal of Political Economy, 24(3), 209-229.

Clark, J. (1939). Social control of business. New York: McGraw-Hill.

Clarkson, M. B. E. (1999). A stakeholder framework for analysing and evaluating corporate social performance. The Academy of Management Review, 20(1), 92-117. 
Claydon, J. (2011). A new direction for CSR: the shortcomings of previous CSR models and the rationale for a new model. Social Responsibility Journal, 7(3) 405-420.

Crane, A., \& Matten, D. (2004). Business ethics. Oxford: Oxford University Press.

Crane, A., \& Matten, D. (2007a). Business ethics (2nd ed.). Oxford: Oxford University Press.

Crane A, Matten D. (2007). Business ethics: Managing corporate citizenship and sustainability in the age of globalization. (2nd ed.) Oxford University Press. https://books.google.jo/books?id=hLLMwe L_TM9cC.

Crane, A., Matten, D., \& Spence, L. (2013). Corporate social responsibility in a global context (September 1, 2013). Chapter in: Crane, A., Matten, D., and Spence, L.J., Corporate Social Responsibility: Readings and Cases in a Global Context, 2/e. Abingdon: Routledge, 3-26. Available online at: SSRN: https:/ssrn.com/abstract= 2322817. file://C:/Users/dell/Tracing/Downloads/SSRN-id2322817.pdf.

Crowther, D. (2008). The maturing of corporate social responsibility: A developmental process. In D. Crowther \& N. Capaldi (Eds.), Research Companion to Corporate Social Responsibility (pp. 19-30). Aldershot: Ashgate.

Dahlsrud, A. (2006). How corporate social responsibility is defined: An analysis of 37 definitions. Corporate Social Responsibility and Environmental Management, 15, 1-13.

Dahlsrud, A. (2008). How corporate social responsibility is defined: An analysis of 37 definitions corporate social responsibility and environmental management. Corporate Social Responsibility and Environment Management, 15(15), 1-13.

Darrag, M., \& E-Bassiouny, N. (2013). An introspect into the Islamic roots of CSR in the Middle East: The case of Savola Group in Egypt. Social Responsibility Journal, 9(3), 362-378. https://doi.org/10.1108/SRJ-10-2011-0096. http://www. emeraldinsight.com/doi/pdfplus/10.1108/SRJ-10-2011-0096.

Davis, K. (1960). Can business afford to ignore social responsibilities? California Management Review, 2(Spring), 70-76.

den Hond, F., Rehbein, K. A., de Bakker, F. G. A., \& Lankveld, H. K.V. (2014). Playing on Two Chessboards: Reputation effects between Corporate Social Responsibility (CSR) and Corporate Political Activity (CPA). Journal of Management Studies, 51(5), 790-813. doi:10.1111/joms.12063.

Detomasi, D. A. (2007). The multinational corporation and global governance: Modelling global public policy networks. Journal Business Ethics, 71, 321-334.

Dicken, P. (2011). Global shift: Mapping the changing contours of the world economy (6th ed.). London: Sage.

Dobers, P., \& Halme, M. (2009). Corporate social responsibility and developing countries. Corporate Social Responsibility and Environmental Management, 16(5), 237-249. doi:10.1002/csr.212.

Drucker, P. F. (1942). The future of industrial man: A conservative approach. New York, NY: John Day Company.

Drucker, P. F. (1984). A new look at corporate social responsibility. McKinsey Quarterly, 4(Autumn), 17-28.

Dunphy, D., Griffiths, A., \& Benn, S. (2003). Organizational change for corporate sustainability. London: Routledge.

Dusuki, A., \& Abdullah, N. (2007). Why do Malaysian customers patronise Islamic banks? International Journal of Bank Marketing, 25(3), 142-160. doi:10.1108/ 02652320710739850.

Edmondson, V. C., \& Carroll, A. B. (1999). Giving back: An examination of the philanthropic motivations, orientations and activities of large black-owned businesses. Journal of Business Ethics, 19, 171-9.

Elkington, J. (1999). Cannibals with forks: The triple bottom line of $21^{\text {st }}$ century business. London: John Wiley and Sons.

EU Commission. (2001). Green paper-promoting a European framework for corporate social responsibility. COM, 2001, 366.

EU Commission (2011). A renewed EU strategy 2011-14 for corporate social responsibility. COM (2011) 681 final, Brussels.

Evans, W. M., \& Freeman, R. E. (1988). A stakeholder theory of the modern corporation. New York: University Press.

Frederick, W. C. (2006). Corporation be good: The story of corporate social responsibility. Indianapolis: Dog Ear Publishing.

Freeman, R. E. (1984). Strategic management: A stakeholder approach. Boston: Pitman.

Freeman, R. E., \& Phillips, R. A. (2002). Stakeholder theory: A libertarian defense. Business Ethics Quarterly, 12(3), 331-350.

Friedman, M. (1970). The social responsibility of business is to increase its profits. New York Times Magazine, 13, 33.

Garriga, E., \& Mele, D. (2004). Corporate social responsibility theories: Mapping the territory. Journal of Business Ethics, 53, 51-71.
Geva, A. (2008). Three models of corporate social responsibility: Interrelationships between theory, research, and practice. Business and Society Review, 113(1), 1-41.

Gholami, S. (2011). Value creation model through corporate social responsibility (CSR). International Journal of Business and Management, 6(9), 148-154.

Gond, J-P., \& Moon, J. (2011). Corporate social responsibility in retrospect and prospect: Exploring the life-cycle of an essentially contested concept, No. 59-2011 ICCSR research paper series-Routledge major work on corporate social responsibility.

Greenfield, W. M. (2004). In the name of corporate social responsibility. Business Horizons, 47(1), 19-28.

Hendry, J., \& Vasilind, P. (2005). Ethical motivations for green business and engineering. Clean Technologies and Environmental Policy, 7(4), 252-258.

Hernández, S., \& Sánchez, P. (2012). The influence of social responsibility policies and belonging to cooperation networks in the relational and structural capital of micro-enterprises. Investigaciones Europeas de Dirección y Economía de la Empresa, 18(2), 166-176. https:/www.scopus.com/record/display.uri?eid=2-s2. 0-84864300153\&origin=inward\&txGid=3638DF8A35C1E927B9AD41DFF3AABC CF.wsnAw8kcdt7IPYLO0V48gA\%3a8.

IMF (International Monetary Fund). (2006). World Economic Outlook: Financial Systems and Economic Cycles. Brussels: International Monetary Fund.

Jamali, D., \& Mirshak, R. (2007). Corporate social responsibility (CSR): Theory and practice in a developing country context. Journal of Business Ethics, 72(3), 243-262. doi:10.1007/s10551-006-9168-4.

Janowitz, M. (1975). Sociological theory and social control. American Journal of Sociology, 81(1), 82-108

Jensen, M. C. (2002). Value maximization, stakeholder theory, and the corporate objective function. Business Ethics Quarterly, 12(2), 235-256.

Johnson, H. L. (1971). Business in contemporary society: Framework and issues. Belmont: Wadsworth Publishing Co., Inc.

Jones, T. M. (1980). Corporate social responsibility revisited, redefined. California Management Review, 22(3), 59-67.

Jonikas, D. (2012). Value creation through CSR at stakeholders level. Economics and Management, 17(2), 693-698.

Kanji, G., \& Chopra, P. (2010). Corporate social responsibility in a global economy. Total Quality Management Business Excellence, 21(2), 119-143.

Kemp, M. (2001). Corporate social responsibility in Indonesia: Quixotic dream or confident expectation? Technology, Business \& Society, (Program Paper No. 6). Geneva, Switzerland: United Nations Research Institute for Social Development.

Kennedy, L. (2001). Ethical funds no longer on the fringe. The Australian Financial Review, 6, 7.

Ketola, T. (2008). A holistic corporate responsibility model: integrating values, discourses and actions. Journal of Business Ethics, 80(3), 419-435. doi:10.1007/ s10551-007-9428-y.

Key, S. (1999). Toward a new theory of the firm: A critique of stakeholder "theory". Management Decision, 37(4), 317-328.

Kok, P., Wiele, T., McKenna, R., \& Brown, A. (2001). A corporate social responsibility audit within a quality management framework. Journal of Business Ethics, 31(4), 285-97.

Kotler, P., \& Lee, N. (2005). Corporate social responsibility: Doing the most good for your company and your cause. Hoboken: Wiley.

Lafferty, W. M. (1996). The politics of sustainable development: Global norms for national implementation. Environmental Politics, 5, 185-208.

Lee, M.-D. P. (2008). A review of the theories of corporate social responsibility: Its evolutionary path and the road ahead. International Journal of Management Reviews, 10(1), 53-73.

Lepak, D. P., Smith, K. G., \& Taylor, M. S. (2007). Value creation and value capture: a multilevel perspective. Academy of management review, 32(1), 180-194.

Levy, N. (2002). Against philanthropy, individual and corporate. Business \& Professional Ethics Journal, 21, 95-108.

Liddell, H. G., \& Scott, R. (1940). A Greek-English lexicon. Oxford: Clarendon.

Lindgreen, A., Swaen, V., \& Campbell, T. (2009). Corporate social responsibility practices in developing and transitional countries: Botswana and Malawi. Journal of Business Ethics, 90(Suppl 3), 429-440. doi:10.1007/s10551-010-0415-3.

Lorenzo, J. M. P., Sánchez, I. M. G., \& Álvarez, I. G. (2009). Características del consejo de administración e información en materia de responsabilidad social corporativa. Revista española de financiación y contabilidad, 141, 107-135. http://dx.doi.org/10. 1080/02102412.2009.10779664.

Lucas, T, Wollin, A, \& Lafferty, G. (2001). Achieving social responsibility through corporate strategy: a matter of governance, 149-155. Available online at: 
http://citeseerx.ist.psu.edu/viewdoc/download?doi=10.1.1.197.5914\&rep= rep1\&type=pdf. Working Paper No.62.

Luna Sotorrío, L., \& Fernández Sánchez, J. L. (2010). Corporate social reporting for different audiences: the case of multinational corporations in Spain. Corporate Social Responsibility and Environmental Management, 17(5), 272-283. https:/doi.org/10.1002/csr.215.

Macve, R. H. (1981). A conceptual framework for financial accounting and reporting: The possibilities for an agreed structure. London: Institute of Chartered Accountants in England and Wales (ICAEW).

Madsen, H., \& Ulhoi, J. P. (2001). Integrating environmental and stakeholder management. Business Strategy and the Environment, 10(2), 77-88.

Maignan, I. (2001). Consumers' perceptions of corporate social responsibilities: A cross-cultural comparison. Journal of Business Ethics, 30(1), 57-72. doi:10.1023/ a:1006433928640.

Maignan, I., \& Ralston, D. (2002). Corporate social responsibility in Europe and the U.S.: Insights from businesses' self-presentations. Journal International Business Study, 33(3), 497-514.

Manakkalathil, J. \& Rudolf, E. (1995). Corporate social responsibility in a globalizing market. SAM Advanced Management Journal, 47, 29-47.

Margolis, J. D., \& Walsh, J. P. (2003). Misery loves companies: Rethinking social initiatives by business. Administrative Science Quarterly, 48, 268-305.

Maron, I. Y. (2006). Toward a unified theory of the CSP-CFP link. Journal of Business Ethics, 67(2), 191-200.

Marsden, C., \& Andriof, J. (1998). Towards an understanding of corporate citizenship and how to influence it. Citizenship Studies, 2(2), 329-352.

Matten, D., \& Moon, J. (2005). A conceptual framework for understanding CSR, chapter 25 in corporate social responsibility across Europe, editors André Habish \& Jan Jonker, (pp335-356). Berlin: Springer Berlin Heidelberg.

Matten, D., \& Moon, J. (2008). "implicit" and "explicit" CSR: A conceptual framework for a comparative understanding of corporate social responsibility. Academy of Management Review, 33(2), 404-424.

McGuire, J. (1963). Business and society. New York: McGraw-Hill.

McWilliams, A., \& Siegel, D. (2001). Corporate social responsibility: A theory of the firm perspective. Academy of Management Review, 26(1), 117-27.

McWilliams, A., Van Fleet, D. D., \& Cory, K. D. (2002). Raising rivals' costs through political strategy: an extension of resource-based theory. Journal of Management Studies, 39(5), 707-723. doi:10.1111/1467-6486.00308.

McWilliams, A., Siegel, D. S., \& Wright, P. M. (2006). Corporate social responsibility: Strategic implications. Journal Management Study, 43(1), 1-18.

Meehan, J., Meehan, K., \& Richards, A. (2006). Corporate social responsibility: The 3C-SR model. International Journal of Social Economics, 33(5/6), 386-398.

Miller, B. W., \& Redding, R. (1986). The FASB: The people, the process and the politics. Homewood, III.: Irwin.

Mohan, A. (2003). Strategies for the management of complex practices in complex organizations: A study of the transnational management of corporate responsibility. Unpublished doctoral dissertation, University of Warwick, United Kingdom.

Moon, J. (2002). Business social responsibility and new governance. Government and Opposition, 37(3), 385-408.

Muirhead, S. A. (1999). Corporate contributions: The view from 50 years. New York: The Conference Board.

Nalband, N.A., \& Kelabi, S.A. (2014). Redesigning Carroll's CSR pyramid model. Journal of Advanced Management Science, 2(3), 236-239. http://www.joams. com/uploadfile/2014/0217/20140217024434433.pdf.

Oppewal, H., Alexander, A., \& Sullivan, P. (2006). Consumer perceptions of corporate social responsibility in town shopping centres and their influence on shopping evaluations. Journal of Retailing and Consumer Services, 13(4), 261-274.

Pearce, J. A., \& Doh, J. P. (2005). High-impact collaborative social initiatives. MIT Sloan Management Review, 46(3), 30-39.

Pedersen, E. R. (2010). Modelling CSR: How managers understand the responsibilities of business towards society. Journal of Business Ethics, 91(2), 155-166. doi:10.1007/s10551-009-0078-0.

Phillips, R. A., Freeman, R. E., \& Wicks, A. C. (2003). What stakeholder theory is not. Business Ethics Quarterly, 13(4), 479-502.

Pinkston, T. S., \& Carroll, A. B. (1994). Corporate citizenship perspectives and foreign direct investment in the US. Journal of Business Ethics, 13(3), 157-169.

Porter, M., \& Kramer, R. M. (2006). Strategy and society: The link between competitive advantage and corporate social responsibility (pp. 78-92). December: Harvard Business Review.

Preston, L. E., \& Post, J. E. (1975). Private management and public policy: The principle of public responsibility. NJ, Prentice-Hall: Englewood Cliffs.
Quran. Verse (2:43), Chapter (2) sūrat I-baqarah (The Cow). Available online at: http://corpus.quran.com/translation.jsp?chapter=2\&verse $=43$.

Quran. Verse (9:103), Chapter (9) sūrat I-tawbah (The Repentance). Available online at: http://corpus.quran.com/translation.jsp?chapter=9\&verse $=103$.

Quran. Verse (9:60), Chapter (9) sūrat I-tawbah (The Repentance). Available online at: http://corpus.quran.com/translation.jsp? chapter $=9 \&$ verse $=60$.

Rizk, R. (2008). Back to basics: An Islamic perspective on business and work ethics. Social Responsibility Journal, 4(1/2), 246-254. doi:10.1108/17471110810856992.

Ross, E. A. (1901). Social Control: A survey of the foundations of order. New York: Macmillan.

Rotchanakitumnuai, S., \& Speece, M. (2003). Barriers to internet banking adoption: A qualitative study among corporate customers in Thailand. International Journal of Bank Marketing, 21(6/7), 312-23. doi:10.1108/02652320310498465.

Rousseau, D. M., Manning, J., \& Denyer, D. (2008). Evidence in management and organizational science: Assembling the field's full weight of scientific knowledge through synthesis. The Academy of Management Annals, 2(1), 475-515.

Sachs, S., \& Ruehle, E. (2009). Sustainable Success with Stakeholders. The Untapped Potential. Basingstoke: Palgrave MacMillan.

Schwartz, M., \& Carroll, A. B. (2003). Corporate social responsibility: A three domain approach. Business Ethics Quarterly, 13(4), 503-30.

Schwartz, M., \& Carroll, A. B. (2008). Integrating and unifying competing and complimentary frameworks: The search for a common core in the business and society field. Business and Society, 47(2), 148-186.

Sethi, S. P. (1975). Dimensions of corporate social performance: An analytical framework for measurement and analysis. California management Review, 17(3), 58-64.

Siwar, C., \& Hossain, M. (2009). An analysis of Islamic CSR concept and the opinions of Malaysian managers. Management of Environmental Quality: An International Journal, 20(3), 290-298. doi:10.1108/14777830910950685.

Smith, A. (1987). The theory of moral sentiments. In R. L. Heilbroner \& L. J. Malone (Eds.), The essential Adam Smith (57-148). New York: W.W. Norton.

Smith, C. (2012). Egypt's Facebook revolution: Wael Ghonim thanks the social network. Huffington Post, 11 February 2012, http://www.huffingtonpost.com/ 2011/02/11/egypt-facebook-revolution-wael-ghonim_n_822078.html.

Stieb, J. A. (2009). Assessing Freeman's stakeholder theory. Journal of Business Ethics, 87(3), 401-414.

Turker, D. (2009). How corporate social responsibility influences organizational commitment. Journal of Business Ethics, 89, 189-204.

UNDP (United Nations Development Programme). (2006). Beyond Scarcity: Power, Poverty and the Global Water Crisis. Brussels: United Nations Development Programme.

Ungericht, B., \& Hirt, C. (2010). CSR as a political arena: The struggle for a European framework. Business and Politics, 12(4), 1-24. DOl.https://doi.org/10.2202/14693569.1303.

Visser, W. (2006). Revisiting Carroll's CSR pyramid: An African perspective. In M. Huniche \& E. P. Rahbek (Eds.), Corporate citizenship in developing countriesnew partnership perspectives (pp. 29-56). Copenhagen: Copenhagen Business School Press.

Visser, W. (2008). Corporate social responsibility in developing countries. In A. Crane, A. McWilliams, D. Matten, J. Moon, \& D. Siegel (Eds.), The Oxford handbook of corporate social responsibility (pp. 473-79). Oxford: Oxford University Press.

Visser, W. (2010). The world guide to CSR. UK: Greenleaf Publishing Limited.

Visser, W. (2011). The age of responsibility: CSR 2.0 and the new DNA of business. West Sussex: John Wiley \& Sons.

Visser, W. (2012). The future of CSR: Towards transformative CSR, or CSR 2.0. Kaleidoscope Futures Paper Series, 1, 1-17.

Visser, W., \& Sunter, C. (2002). Beyond reasonable greed: Why sustainable business is a much better idea! Cape Town. Tafelberg Human \& Rousseau.

Visser, W., Matten, D., \& Pohl, M. (2007). The A to Z of CSR: An international encyclopaedia of concepts, codes and organisations. London: Wiley.

Wartick, S. L., \& Cochran, P. L. (1985). The evolution of the corporate social performance model. Academy of Management Review, 10, 758-69.

Wheeler, D., Colbert, B., \& Freeman, R. E. (2003). Focusing on value: Corporate social responsibility, sustainability and a stakeholder approach in a network world. Journal of General Management, 28(3), 1-28.

Whelan, G. (2012). The political perspective of corporate social responsibility: a critical research agenda. Business Ethics Quarterly, 22(4), 709-737. https://doi.org/10.5840/beq201222445.

Windsor, D. (2001). The future of corporate social responsibility. International Journal of Organizational Analysis, 9(3), 225-256.

Wood, D. J. (1991). Corporate social responsibility revisited. Academy of Management Review, 16, 691-718. 
Wood, D. J. (2010). Measuring corporate social performance: A review. International Journal of Management Reviews, 12(1), 50-84.

Wood, D., \& Jones, R. (1996). Research in corporate social performance: What have we learned. In B. Dwight., \& Y. Dennis (Eds.), Corporate philanthropy at the crossroads. Bloomington: Indiana University Press.

World Bank. (2006). World Development Report 2007: Development and the Next Generation. Washington: World Bank.

WRI (World Resources Institute). (2005). World Resources 2005: The Wealth of the Poor - Managing Ecosystems to Fight Poverty. Washington, D.C: World Resources Institute, UNDP, UNEP, World Bank

\section{Submit your manuscript to a SpringerOpen ${ }^{\bullet}$ journal and benefit from:}

- Convenient online submission

Rigorous peer review

- Open access: articles freely available online

- High visibility within the field

- Retaining the copyright to your article

Submit your next manuscript at $\gg$ springeropen.com 